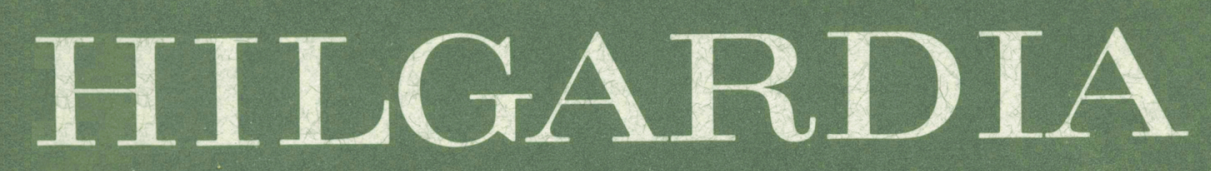

AJOURNAL OF AGRICULTURAL SCIENCE PUBLISHED BY THE CALIFORNIA AGRICULTURAL EXPERIMENT STATION

Volume 47, Number 6・ December, 1979

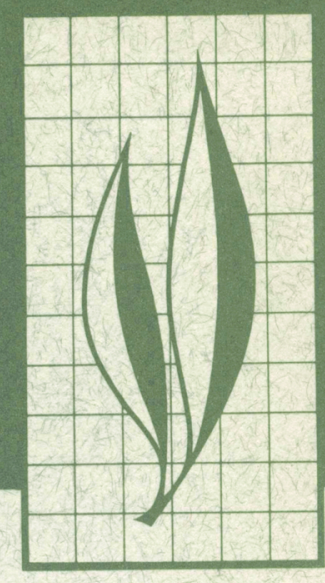

\title{
Food Interrelationships of Deer and Sheep in Parts of Mendocino and Lake Counties, Califomia
}

William M. Longhurst, Guy E. Connolly, Bruce M. Browning, and Edward O. Garton

End of Volume 


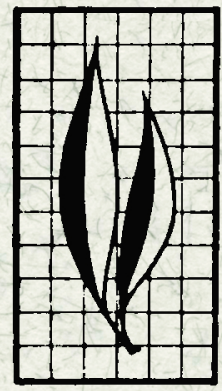

Between 1951 and 1975, range forage interrelationships and food habits of black-tailed deer and domestic sheep were studied on the Hopland Field Station of the University of California. Other nearby areas with contrasting covertypes were compared.

Data were collected on percent of volume and frequency of occurrence of forage plant species in samples of rumen contents taken from animals collected on the various range types. Browse preferences were compared in a series of "cafeteria" feeding trials with penned animals, and correlations with phosphorus and protein content were tested.

Little significant forage competition between deer and sheep was found, although chaparral browse was limited. In general, diets of these animals were complementary, with deer relying primarily on browse, and sheep on grass. In other range types, deer had a wide latitude in their dietary patterns, depending upon availability of preferred forage species.

In browse preference feeding trials, where grasses were excluded from the diet of sheep, both deer and sheep tended to select or reject the same browse species; their palatability did not correlate with phosphorus or protein content when measured on a dry weight basis. However, deer preference ranking correlated significantly with plant protein content determined on a green weight basis.

Relationships between forage consumption and forage production on the field station were also evaluated. Production of all forage classes except chaparral browse exceeded estimated consumption by wide margins. However, combined browsing by sheep and deer substantially reduced oak seedlings and will eventually lower browse, mast, and lichen production. Sheep grazing on Hopland Field Station maintains grassland in a productive seral stage, which raises the carrying capacity for deer over that which would exist without livestock.

The Authors:

W.M. Longhurst is Professor, Department of Agronomy and Range Science, University of California, Davis.

G.E. Connolly, formerly Staff Research Associate, Division of Wildlife and Fisheries Biology, University of California, Davis, is Wildlife Research Biologist, U.S. Fish and Wildlife Service, Twin Falls, Idaho.

B.M. Browning is Associate Wildlife Manager Biologist, California Department of Fish and Game, Sacramento.

E.O. Garton, formerly Lecturer, Division of Environmental Studies, University of California, Davis, is Assistant Professor of Wildlife, College of Forestry Wildlife and Range Sciences, University of Idaho, Moscow, Idaho. 


\section{William M. Longhurst, Guy E. Connolly, Bruce M. Browning, and Edward O. Garton \\ Food Interrelationships of Deer and Sheep in Parts of Mendocino and Lake Counties, California ${ }^{1}$}

\section{INTRODUCTION}

Many PUblic AND PRIVATE RANGelands in the western United States are subject to dual use by livestock and big game, and the manager of such lands is faced with possible competiton for forage between the two classes of animals. Effects of the animals on the range and, conversely, of the range on the animals are of equal importance. A number of different approaches have been used to study these relationships.

The production and consumption of forage can be estimated by comparing ungrazed and grazed areas. Vegetation on small fenced and unfenced plots may be clipped and weighed, or the general effects of grazing can be assessed visually. Such comparisons have been made in various range types by McKean and Bartman (1971), Drawe and Box (1968), Skovlin, Edgerton, and Harris (1968), and Mackie (1970). Some variations on this approach were given by Martin, Gensch, and Brown (1970).

Consumption can also be determined by observing animals as they feed either on the range or in captivity. Bjugstad, Crawford, and Neal (1970), Buechner (1950), and Wallmo and Neff (1970) have summarized these methods with livestock and deer. Neff (1974) and Wallmo et al. (1973) also used trained deer that could be handled and transported to field sites where their foraging behavior was observed.

Some laboratory measures of forage consumption rely on internal chemical indicators, such as lignin ratios, chromogens, and silca (Theurer, 1970). Esophageal or rumen fistulae have also been installed in test animals to facilitate such studies (Rice, 1970).

Direct analyses of stomach contents and feces to determine the kinds and amounts of forage plants consumed by herbivores, both wild and domestic, were evaluated by Medin (1970), Ward (1970), Norris (1943), and Anthony and Smith (1974). Klein (1962) used the nutrient content of rumen samples to determine range quality for deer populations.

The present study focuses primarily on how Columbian black-tailed deer (Odocoileus hemionus columbianus) and domestic sheep use the rangeland of the Hopland Field Station of the University of California which they share in common. Additionally, deer food habits were investigated in two other cover types not represented on the field station.

This report includes (1) a comparison of the food habits of deer and sheep using rumen-sample analysis; (2) an assessment of deer food habits in each vegetation cover type; (3) an appraisal of the relative palatability of the principal browse species occurring on the field station; and (4) estimation of the range forage requirements of deer and sheep and their relationship to forage production and availability. 


\section{METHODS}

\section{The primary study area}

The principal study area was the Hopland Field Station, where we have investigated the biology of black-tailed deer and their interrelationships with domestic sheep (Ovis aries) since 1951 . This station of over 2,100 ha is in southwestern Mendocino County about $160 \mathrm{~km}$ north of San Francisco Bay. Before its acquisition by the University of California in 1951, it was a commercial sheep ranch. The general area has a history of livestock grazing dating back at least to the preceding century.

The rangeland on the station is primarily annual grassland, some with an overstory of various species of oaks or other hardwoods, and interspersed with patches of chaparral. A few douglas fir (Pseudotsuga menziesii) trees are present in the more mesic sites.

When this study began in 1951, the station encompassed approximately 1,893 ha. Subsequently, in 1954, 16 ha and, in 1965, 259 ha of adjoining public land were acquired from the Bureau of Land Management to give a total of 2,168 ha. Some of the University ownership has not been fenced because of the steep terrain and lack of accessibility.

The Hopland Field Station extends from the floor of the Russian River valley to the ridge of the Mayacamas Mountains, where public domain lands 2 extend northward from the station. This 22,000 ha-area, which is dominated by dense stands of mixed chaparral, was designated as the Cow Mountain Recreation Area by executive order in 1927. A survey of the vegetational cover types was carried out by Heady and Mallory (1955) on the original field station area, and this provides a good sample of the vegetation present (table 1).

TABLE 1.

COVER-TYPE DISTRIBUTION ON THE FENCED AREA, HOPLAND FIELD STATION

\begin{tabular}{lcr}
\hline \multicolumn{1}{c}{ Cover type } & Area \\
\hline & & percent \\
Grassland & bectares & 23 \\
Woodland grass & 435 & 36 \\
Woodland & 697 & 22 \\
Chaparral & 413 & 15 \\
Wet meadows and ponds & 286 & $<1$ \\
Cultivated & 8 & 4 \\
Total & 1,918 & 100 \\
\hline
\end{tabular}

SOURCE: cover-type map from Heady and Mallory, (1955)

*Approximately 3 percent of grassland has some chaparral.

The complex mosaic of vegetation, which in turn basically reflects the soil-type distribution, is illustrated in the cover type and soil maps for the station (Figs. 1,2). Gowans (1958) succinctly described the soils on the station:

"Geologically, the area is part of the Franciscan Formation (Jurassic). This formation consists of plastic and chemical sediments with intrusive and extrusive igneous rocks. Hard, fractured sandstones and shales are the dominant rocks. The medium-textured soils of the Laughlin, Sutherlin, Maymen, Los Gatos, Hugo, and Josephine series are found on these rocks. The Stonyford and Sobrante series have formed on localized areas of basalt. The Yorkville soils are derived from glaucophane schist which has a rather wide distribution in the area. Small areas of ultra basic rocks and metamorphic rocks of basalt and sandstone occur from which the Henneke, Climax, and Montara soils are derived."

${ }^{2}$ Public domain lands have generally been designated as national resource lands since 1973 . 


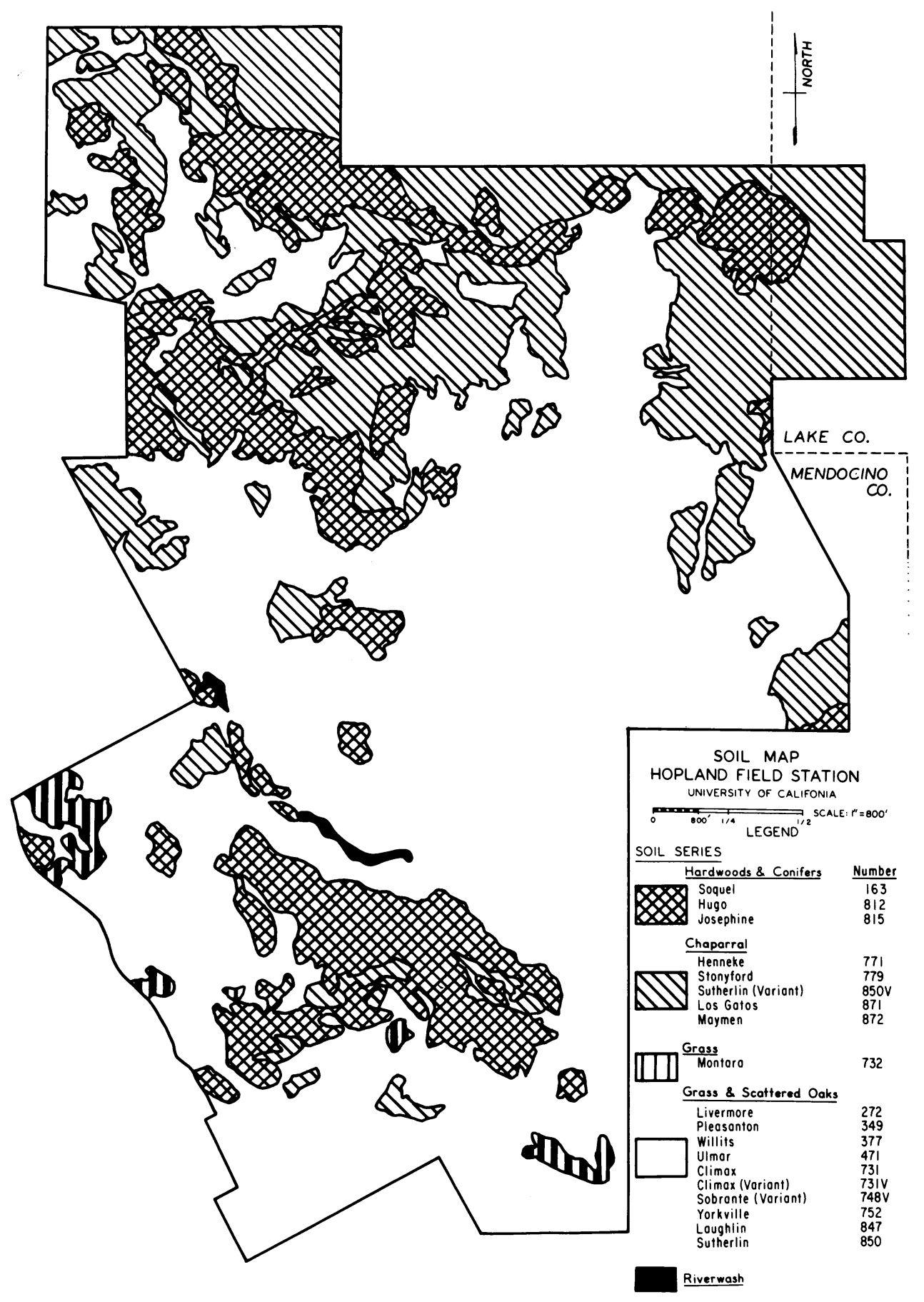

Fig. 1. Soil Map, Hopland Field Station. Adapted from Soil Survey of the Hopland Field Station (Gowans, 1958). 


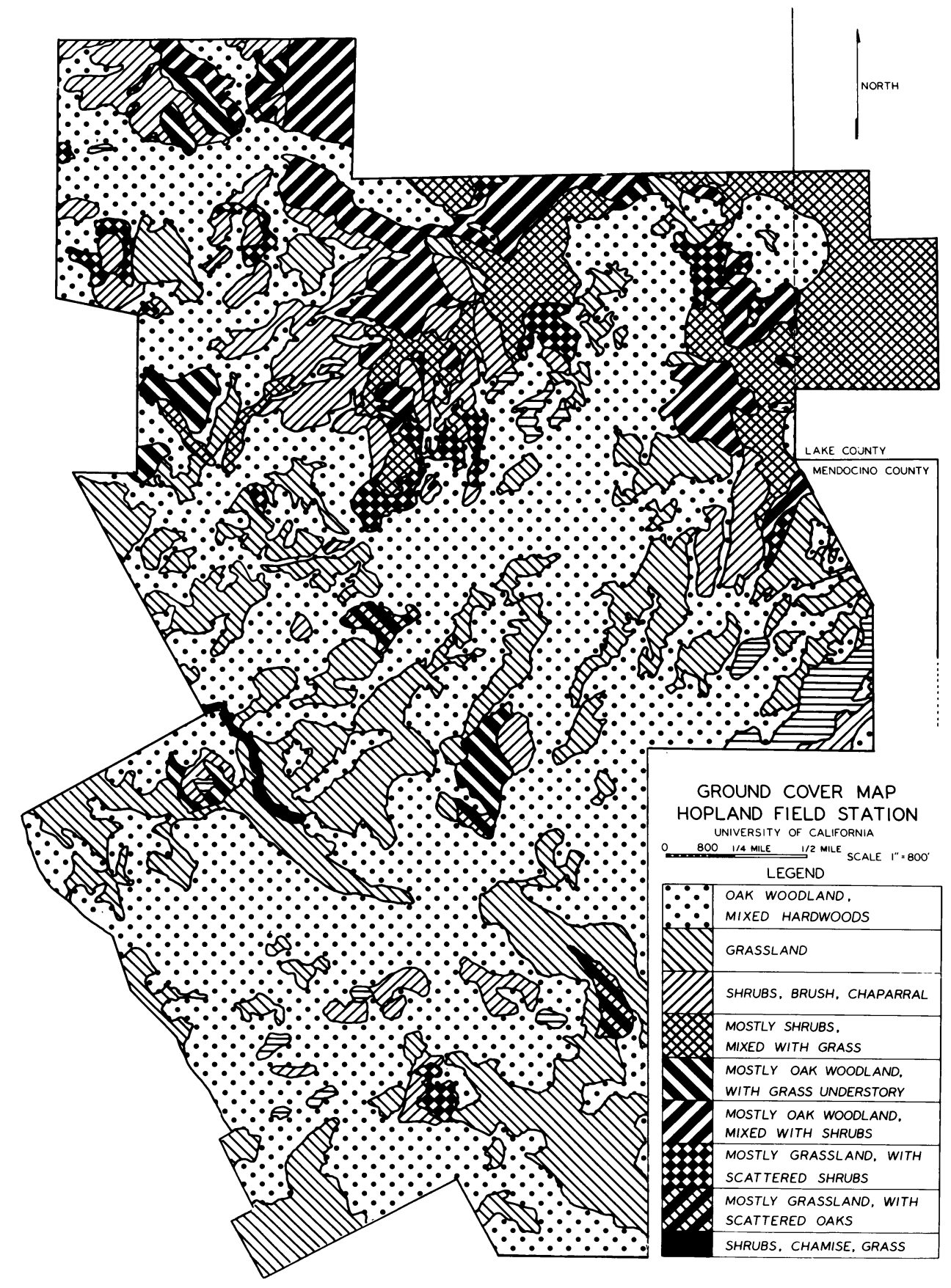

Fig. 2. Ground cover map, Hopland Field Station. Adapted from cover type map (Heady and Mallory, 1955). 
TABLE 2.

SOILS, HOPLAND FIELD STATION

\begin{tabular}{|c|c|c|c|}
\hline Soil Series & Number * & Parent material & Native vegatation \\
\hline Livermore & 272 & Alluvium-sedimentary rock & $\begin{array}{l}\text { Grass with scattered blue and } \\
\text { valley oaks }\end{array}$ \\
\hline Pleasanton & 349 & $\begin{array}{l}\text { Alluvium from out-washed } \\
\text { sandstone and shale }\end{array}$ & Grass with scattered blue oaks \\
\hline Willits & 377 & $\begin{array}{l}\text { Alluvium from sedimentary } \\
\text { rocks }\end{array}$ & $\begin{array}{l}\text { Grass with scattered valley } \\
\text { oaks }\end{array}$ \\
\hline Ulmar & 471 & $\begin{array}{l}\text { Alluvium from sandstone } \\
\text { and shale }\end{array}$ & $\begin{array}{l}\text { Grass and forbs with scattered } \\
\text { valley oaks }\end{array}$ \\
\hline Climax (variant) & $731731 \mathrm{~V}$ & Metamorphosed basaltic rock & $\begin{array}{l}\text { Grass with occasional blue } \\
\text { oaks }\end{array}$ \\
\hline Montara & 732 & Serpentine rock & Sparse grass and forbs \\
\hline Sobrante (variant) & $748 \mathrm{~V}$ & Basic igneous rocks & Grass with scattered blue oaks \\
\hline Yorkville & 752 & $\begin{array}{l}\text { Schist and related } \\
\text { metemorphic rocks }\end{array}$ & $\begin{array}{l}\text { Grass with blue and valley } \\
\text { oaks }\end{array}$ \\
\hline Laughlin & 847 & Sandstone and shale & $\begin{array}{l}\text { Grass with blue and interior } \\
\text { live oaks }\end{array}$ \\
\hline Southerlin & 850 & Sandstone and shale & $\begin{array}{l}\text { Grass with blue and interior } \\
\text { live oaks }\end{array}$ \\
\hline Henneke & 771 & Serpentine rock & $\begin{array}{l}\text { Chaparral, hoary manzanita, } \\
\text { leather oak, chamise, } \\
\text { Macnab cypress }\end{array}$ \\
\hline
\end{tabular}

${ }^{\star}$ Soil Series number as used by the California State Cooperative Soil Vegetation Survey.

Table 2 gives additional details on the relationships between the soil series, their parent materials, and the dominant vegetation associated with them. There is some disagreement between the distribution of soil types and cover in figures 1 and 2; this appears to result primarily from the criteria used to describe cover types by the authors of the two original maps from which figures 1 and 2 were condensed. The main purpose of presenting this information in the present report is to illustrate the complexity of the mosaic of soil and vegetation types present on the Hopland Field Station.

Much of the land on the station has a steep gradient, and the property extends from the east edge of the Ukiah Valley near the Russian River with an elevation of approximately 183 meters, up the western slope of the Mayacamas Mountain range to an elevation of slightly over 900 meters. The general aspect of most of the land is south to southwest, though there are small areas of north-facing slope.

Climate in this area is typically Mediterranean with hot, dry summers and cool, moist winters. Annual precipitation averaged $1,054 \mathrm{~mm}$ for the periods of the study, 1951 to 1954 and 1963 to 1973. Most precipitation comes between October and May in the form of rain, but there are usually several light snowfalls each winter mostly at the higher elevations. Snow seldom persists for more than a few days at a time. The mean temperature for this period was $13.47 \mathrm{C}$, with minimum and maximum means of 5.62 and $22.24 \mathrm{C}$, respectively.

Because of the diversity and interspersion of cover types on the station, the use by deer and sheep is well distributed. Still, deer distribution is probably somewhat more uniform than that of sheep, because sheep are confined to certain pastures and rotated among various pastures seasonally. The deer in contrast, range freely over the entire area except for a few pastures with deer-proof fencing. Likewise, sheep tend to avoid areas of dense chaparral cover, though deer routinely penetrate these thickets and use them extensively for bedding sites and escape cover. 


\section{Deer status}

During deer investigations at Hopland, a live-trapping and marking study was carried out from 1954 through 1974. The movements of individually marked deer showed that they had very localized home ranges. Once deer established themselves on a home range, usually at an age between 1 and 2 years, they tended to remain there throughout their lives. Home ranges for bucks average $285 \mathrm{ha}$, while those of does average only 207 ha.

Some of the deer shifted their ranges seasonally, wintering in the upper, oak woodland areas of the station and moving north off the station into the Cow Mountain area to take advantage of the more abundant browse there. Although such movements rarely exceeded $1.6 \mathrm{~km}$ and could not be considered a true migration, it was evident that the entire range area should be studied as an ecological unit.

Detailed soil and vegetation studies were confined to the station proper, but deer were collected on the Cow Mountain area to sample their food habits in the chaparral environment. Deer were sampled year-round in burned chaparral and seasonally in mature chaparral that had not been burned for at least 25 years.

Since 1951, several estimates of deer numbers have been made by sample area count, pellet group count, and change-in-ratio methods based on Lincoln and Kelker indices (Lincoln, 1930; Kelker, 1940, 1943); also see Overton (1969) and Eberhardt (1969). These estimates ranged between 570 and 1,890 deer with an average of about 1,000, or one deer per 2 ha. A detailed seasonal series of estimates for the period 1964 to 1966 was calculated from hunter kill, trapping, autopsy, carcass examination, and herd composition data. These calculations showed that a deer population varying seasonally from about 480 to 740 animals was necessary to support the known buck kill by hunters (Connolly, 1970). Similar calculations for the years 1964 to 1969 gave an average deer population ranging seasonally from about 550 to 900 animals, or one deer for each 2.3 to 3.7 ha. During these years, approximately 12 percent of the deer were removed annually by hunters and research workers, while about 25 percent more were estimated to have died of natural causes. The annual mortality rate thus averaged about 37 percent (Anderson et al., 1974). This figure includes fawn death losses, which approximate 50 percent between birth and 12 months of age. The deer population appears to be stable within the limits of climatic and forage variations. Perhaps the best evidence of this is that the annual buck kill is fairly constant over the years (Connolly and Longhurst, 1975). Hunting pressure is also quite constant.

The dense deer population in this area makes competition for available forage resources keen at certain seasons. Anderson et al. (1974) have hypothesized how this food competition may affect the dynamics of the deer population. Such competition also affects the abundance and growth characteristics of the food plants, as discussed later in this report.

\section{Sheep status}

Sheep operations on the station through the years have generally followed the practices of commercial ranches in this part of California. However, because of the experimental program, certain modifications have developed.

For example, barn-lambing has been adopted to increase the survival of lambs which are born from late December through February. Not all lambs were born in the barns during the early years of the research program, but by 1954 virtually all were. The net 
result of barn-lambing is that lamb survival is significantly better on the station than on most commercial sheep ranches in the area.

Nutritional deficiencies are present in the range forage plants at certain seasons, and sheep are supplemented with hay and various concentrates in an attempt to bridge the gap between nutrients supplied by the range and nutrients needed for increased production. An average of about 107 metric tons of alfalfa hay were purchased and fed each year. In addition 454 to $680 \mathrm{~kg}$ of alfalfa meal, 2.7 to 4.5 metric tons of milo, 9 to 13.6 metric tons of cottonseed meal, and 4.5 to 22.7 metric tons of barley were used. The use of these supplements reduced sheep grazing pressure on the range at certain times of year, and a larger sheep population was maintained than could have been sustained by range forage alone.

Sheep numbers on the station have varied seasonally, as have deer, as a result of recruitment of young and losses of various kinds. The basic difference between the sheep and deer populations is that sheep numbers are controlled by planned removals of excess animals (lambs and culls) to keep numbers in balance with the range-carrying capacity, whereas hunting and scientific collections did not appear to limit deer numbers. The deer were regulated primarily by the food supply. Competition among deer for available forage is much greater than among sheep.

Sheep on the Hopland Field Station produce approximately 140 lambs per 100 breeding ewes, ${ }^{3}$ whereas the deer average only about 112 fawns per 100 breeding does (Anderson et al., 1974). Resident deer herds in this part of the state typically have a lower reproductive rate than that of migratory herds found in the higher mountainous areas of California. Does of prime breeding age ( 4 to 7 years at parturition), produce about 150 fawns per 100 does at Hopland. The lower figure above is a weighted average, based on the age structure of the population.

Fawn production does vary from year to year, apparently as a result of climate-induced changes in the quantity and quality of forage (Anderson et al., 1974). The birth rate for sheep is more stable because of the supplemental feed they receive at critical seasons. Likewise, because excess numbers of breeding males are not maintained in the sheep flock, a higher proportion of the flock is composed of breeding females than is true in the case of deer-with the result that the total number of young produced by sheep is greater than for deer. Thus, more turnover occurs in the sheep population. Numbers of sheep maintained on the station during the years of the food habits study (1951 to 1954; 1963 to 1973 ) are given in Table 3.

TABLE 3.

SHEEP NUMBERS DURING RUMEN SAMPLING PERIODS, HOPLAND FIELD STATION

\begin{tabular}{crcc}
\hline Year & Ewes $^{*}$ & Rams & Lambs \\
\hline 1952 & 1250 & 21 & 630 \\
1953 & 1074 & 26 & 559 \\
1954 & 883 & 23 & 695 \\
1955 & 1025 & 21 & 827 \\
1963 & 927 & 46 & 856 \\
1964 & 1018 & 51 & 1073 \\
1965 & 1358 & 40 & 1282 \\
1966 & 1281 & 54 & 1318 \\
\hline
\end{tabular}

\begin{tabular}{cccc}
\hline Year & Ewes $^{*}$ & Rams & Lambs \\
\hline 1967 & 1267 & 55 & 1030 \\
1968 & 1293 & 56 & 1176 \\
1969 & 1480 & 65 & 1533 \\
1970 & 1382 & 56 & 1575 \\
1971 & 1239 & 51 & 1305 \\
1972 & 1206 & 65 & 1422 \\
1973 & 1257 & 41 & 1355 \\
Average & 1196 & 45 & 1109 \\
\hline
\end{tabular}

${ }^{\star}$ Replacements included.

\footnotetext{
In recent years the lambing percentage has averaged about 140 per 100 ewes, but in the early years of the station's operation it was somewhat less.
} 


\section{Animal weights and forage requirements}

Since the University acquired the Hopland Field Station in 1951, all deer captured or shot for any purpose have been weighed. Thus a substantial body of data is available to estimate average deer weights at various seasons. The average weight used in this report was calculated from 898 individual live weights of bucks and does. Even more weight data are available for the sheep, all of which were routinely weighed at least four times per year. Birth weights of lambs also were regularly recorded.

Deer herd composition counts were taken each year in July, Ocotber, and April. Inventories of the sheep flock were taken at weighing times and frequently when sheep were moved from one pasture to another. From these data it was possible to calculate with reasonable accuracy the weight of the average sheep and deer on the station throughout the year, taking into account the prevailing sex ratios and ratios of young to adults at various seasons. Likewise, the estimated numbers of animals present allowed calculation of the average total biomass for each species (refer to the previous sections on the status of deer and sheep).

Estimates of weights of forage required to support deer and sheep were drawn from the literature. Bissell et al. (1955) carried out feeding trials with both black-tails and mule deer in California and showed that food intake varied, depending on the digestibility of the ration, from less than 1 percent to 2.7 percent of body weight per day. The average maintenance diet was about 2.35 percent of live weight per day.

Sheep forage requirements were based on information given in the National Academy of Sciences, National Research Council publication on nutrient requirements of sheep (1975). A figure of 2.92 percent of body weight per day was determined by averaging the requirements quoted in the NAS, NRC report for various ages, weights and sexes of sheep. These requirements ranged from 1.6 to 5.0 percent of body weight per day. The special feed requirements for pregnant and lactating ewes were also considered in this determination. From these data the forage requirements for the sheep flock and the deer population could be estimated. In turn, a comparison was possible between forage production and the animals' requirements.

\section{Sampling procedure-rumen samples}

To compare the diets of sheep and deer on the field station, samples of rumen contents were collected from animals shot on the range during two sampling periods: November 30, 1951, to February 8, 1954, and September 18, 1963, to October 4, 1973.

At the outset of this study, an effort was made on the field station to obtain five deer and five sheep samples for each month throughout the year. Because the animals collected for this study were also being used for a number of other investigations, it did not prove feasible to complete collections during the initial year of sampling. Collecting was therefore extended over several years, and, in the final analysis, most of the animals from which rumen samples were saved were taken primarily for other studies. A number of deer samples were also collected from bucks shot by hunters each year in August and September.

An aliquot of approximately $500 \mathrm{ml}$ of the stirred rumen contents was saved from each animal and preserved in 10 percent formalin. Periodically, stored samples were sent to the Food Habits Laboratory of the California Department of Fish and Game in Sacramento for analysis. Samples collected from 1951 to 1954 were analyzed under the direction of Howard R. Leach, while analysis of those taken from 1963 to 1973 was supervised by Bruce M. Browning. 
For analysis, a portion of the rumen sample was thoroughly washed in a sieve ( 7 mesh per $\mathrm{cm}$ ) and examined under a binocular microscope equipped with $10 \times$ ocular and 0.7-3 $\times$ objective lenses. After identification, a visual estimate of the percentage of each item in the sample was made and recorded. Results therefore, are an index, not an absolute measure of proportions of various food items in the diet. No effort was made to carry out precise quantitative determinations.

Data were summarized by the aggregate percentage method described by Martin, Gensch, and Brown (1946) in terms of percentage volume and frequency of occurrence.

\section{Other study areas}

For comparative purposes, analyses of deer rumen collections from three other areas are included in this report. One series of 14 samples was collected during three months in Boundary Basin, an area of mature chaparral unburned since the 1940s in Lake County on the Cow Mountain Recreation Area some five $\mathrm{km}$ northeast of the Hopland Field Station. These were combined with 41 samples taken by Taber and Dasmann (1958) from mature chaparral in the same general locality. The third collection includes 47 samples from Masonite Corporation land in Mendocino County northwest of Ukiah. The Masonite property is managed for commercial production of Douglas fir and redwood timber. Much of the area is dominated by second-growth conifers intermixed with hardwoods, with understory brush species and patches of chaparral. Some experimental plantings of eucalyptus have been made in the area, and remnants of abandoned homestead family fruit orchards remain at a few sites.

The January and February Masonite deer samples were from animals shot in 1966 by Masonite personnel during a damage-control effort to reduce deer browsing on experimental eucalyptus and Douglas fir plantings. The remainder of the Masonite deer were taken by University personnel from 1966 to 1970 in connection with various rumen physiology studies.

In total, 80 sheep and 363 deer rumen samples were examined from the field station and the adjacent Cow Mountain area. Additionally, as mentioned earlier, 14 deer samples from the Boundary Basin area, plus 41 collected by Taber and Dasmann (1958), and 47 from Masonite property were analyzed, totaling 465 .

\section{Habitat}

Information on the vegetation present on the study area was obtained primarily from data gathered by other investigators working either directly on the field station or on the adjacent Cow Mountian area. For example, data on chaparral browse production were obtained from Taber (1956). Grassland production and composition information are from Van Dyne and Heady (1965a), Murphy (1970), Heady (1958), and Pitt (1975). Additionally, personal communications from Heady ${ }^{4}$ and Spruill, 5 respectively have provided information on grassland production under an oak overstory, and acorn production by blue oaks.

Ever since the field station was established in 1951, continuous effort has been made to identify all the species of plants occurring on the area. A.H. Murphy, superintendent at the station, and H.F. Heady, professor of forestry at U.C. Berkeley, and others, have

${ }^{4}$ H.F. Heady, Professor of Forestry, University of California, Berkeley.

J.H. Spruill, California Department of Fish and Game, Sacramento. 
contributed to this plant collection. Some 95 species of grass, 13 species of grass-like plants (rushes and sedges), 374 species of forbs (broad-leafed herbaceous plant), and 77 species of woody plants (trees and shrubs, many of which are browse plants) have been found on the station, to give a total of 559 species of vascular plants. Additionally, three genera of arboreal lichens that deer feed upon have been identified. Plant names for the botanical collections from the field station and rumen sample analyses follow Hitchcock (1951) for grasses, and Munz and Keck (1975) for all other species.

\section{Habitat manipulation}

A number of studies on the Hopland Field Station have involved the removal of woody vegetation, both trees and chaparral, and their replacement on about 187 ha by grassland. Clearing has been accomplished by bulldozing and discing, burning and the use of herbicides. In addition, about 20 ha of chaparral on the station have been burned at various times, but no follow-up treatment by mechanical or chemical applications were used. The chaparral regrowth from root crown sprouts and seedlings has largely revegetated these areas.

About 1,300 ha of the Cow Mountain area adjacent to the field station are frequented seasonally by deer from the station. Approximately 890 ha of this chaparral range was burned between 1951 and 1973; most of the burned areas were under 15 ha in size. Some areas were reburned one or more times during this period, while other areas such as north-facing slopes which are more fire-resistant have remained unburned. Most of the controlled burns were made from 1963 through 1968, when a special effort was made to appraise the value of small burns as a deer-management practice (Longhurst and Connolly, 1970).

In contrast to the burned chaparral near the field station, the Boundary Basin portion of the Cow Mountain area, some five km east of the field station, has not been burned since the late 1940s. Deer rumen samples from this area were compared with those from the burned chaparral to appraise the influence of brush burning on the deer diet.

\section{Browse palatability-cafeteria feeding trials}

Both sheep and deer are known to be selective in their choice of forage plants, and the various factors that influence forage selection have been investigated by numerous workers (Freeland and Janzen, 1974; Longhurst et al., 1968; Van Dyne and Heady, 1965a, 1965b, 1965c; Van Dyne and Meyer, 1964; Van Dyne and Torell, 1964; Weir and Torell, 1959; Heady, 1964). In this study we assessed the relative palatability of the common browse species using captive animals.

An extensive series of "cateteria" feeding trials was carried out from May through October, 1962; objectives were to: 1) establish a preference order for the abundant browse species occurring on the station; 2) determine monthly changes in palatability correlated with plant phenology; 3) correlate palatability with nutrient content of the plants; and 4) determine how sheep and deer made their selections. It was expected that phenological changes in the plants would affect the monthly palatability rank of each plant, though such variations are difficult to analyze quantitatively.

The establishment of a browse preference order by means of feeding trials is complicated by a number of variables, many of which are largely uncontrollable. In the 1962 feeding trials, uniformity of procedure was attempted to the greatest extent possible. 
On the morning that feeding trials were to be run, browse samples from the range were cut and kept under canvas with moist burlap sacks to prevent wilting until they could be fed to the deer and sheep. Individual browse species were generally cut from the same plant on the same area for each trial in an attempt to avoid palatability variations from different sites, soil types, and elevational levels. Whenever possible, the brush collections were limited to browse that was actually available to deer. For the more palatable species, though, we found that all forage within the reach of deer was gone by late summer.

Three pairs of penned deer and three pairs of penned sheep, all adult females, were used in the feeding trials. Each pair was offered three samples, one branch from each of three browse species, placed in a pile on the ground in the pen. The observer would then watch from a distance to see which species was most preferred and which was least preferred. If the first branch encountered was highly acceptable, the animals often ate it before evaluating the other samples. Less palatable offerings, however, were usually smelled and not fed upon until the entire set of available samples had been similarly inspected. Once the animals began to eat, they usually concentrated on one branch and consumed most of it before moving to another species. The preferred plant was then replaced by a new plant, and the animals were permitted to make another selection. By conducting a succession of such trials, a rough order of preference was established.

Each set of three species was offered to each of the three trial groups of sheep or deer in turn, providing three replications of each test. Generally, each of the three groups would select the same browse species as most palatable, and they would concur in their choice of the least palatable species. At times, however, two groups agreed, whereas the third group or one member of a group would differ in its choice of the most palatable plant. It soon became obvious that individual animals consistently differed in their preferences. This phenomenon was noticed especially with the sheep. For example, one ewe preferred blue oak (Quercus douglasii) to valley oak (Q. lobata), while two other ewes could be relied upon to prefer valley oak to blue oak. Such differences were seen only with species that ranked close together in preference. The results reported in tables 4 and 5 reflect majority preferences.

In this study we thought it important to investigate the relationship, if any, between preference rank and protein content of the various browse species. Therefore we measured Kjeldahl nitrogen (Horwitz, 1960), as an indicator of protein content, for each browse species in each month of the study (table 6). Browse samples were dried for 16 hours at $100^{\circ} \mathrm{C}$ and then ground in a Wiley mill and stored in air-tight bottles until analyzed. Each sample was weighed before and after drying, and the weights used to calculate protein content in the fresh samples (green basis, table 6). Total phosphorus in dried ground browse samples was determined by the method of Bridges, Boyland, and Market (1953). As with protein determinations, the phosphorus values were expressed both on dry weight and green weight bases (table 7).

\section{Results}

The analyses of rumen samples are summarized in tables 8, 9 and 11 through 15, and illustrated in figures 3 through 9 . Data are listed by forage species, in order of importance, divided into three general forage classes: browse (woody species and their fruits); forbs (herbaceous, broad-leaved species and lichens); and grasses (monocotyledonous grasses, grass-like sedges and rushes, and domestic grain). Data are further separated by month of collection and are given in terms of percent of volume and percent of frequency of occurrence. Origins of forage plants identified in rumen samples of deer and sheep collected on the Hopland Field Station are listed in Table 10. 
TABLE 4.

DEER BROWSE PREFERENCES DURING FEED TRIALS, MAY TO OCTOBER, 1962.

\begin{tabular}{|c|c|c|c|c|c|c|c|c|c|}
\hline \multirow{2}{*}{$\begin{array}{l}\text { Overall } \\
\text { preference } \\
\text { rank }\end{array}$} & \multirow{2}{*}{$\begin{array}{c}\text { Monthly } \\
\text { average } \\
\text { rank }\end{array}$} & \multirow[b]{2}{*}{ Common name } & \multirow[b]{2}{*}{ Scientific name } & \multicolumn{6}{|c|}{ Monthly rank $\mathrm{f}$} \\
\hline & & & & May & June & July & Aug. & Sept. & Oct. \\
\hline 1. & 2.5 & Mistletoe & Phoradendron villosum & 3 & 3 & 2 & 3 & 3 & 1 \\
\hline 2. & 3.2 & Lichen & Ramalina reticulata * & 5 & 1 & 1 & 1 & 1 & 10 \\
\hline 3. & 4.0 & Poison oak & Rhus diversiloba & 8 & 4 & 3 & 2 & 2 & 5 \\
\hline 4. & 4.3 & Mt. mahogany & Cercocarpus betuloides & 2 & 2 & 4 & 4 & 7 & 7 \\
\hline 5. & 5.0 & Valley oak & Quercus lobata & 4 & 6 & 6 & 6 & 4 & 4 \\
\hline 6. & 6.0 & Black oak & Q. kelloggii & 1 & 7 & 7 & 9 & 9 & 3 \\
\hline 7. & 8.3 & Blue oak & $Q$. douglasii & 7 & 5 & 9 & 10 & 10 & 9 \\
\hline 8. & 8.7 & Elderberry & Sambucus glauca & 18 & 9 & 8 & 5 & 6 & 6 \\
\hline 9. & 8.7 & Buckeye & Aesculus californica & 19 & 14 & 5 & 7 & 5 & 2 \\
\hline 10. & 9.2 & Sweet birch & Ceanothus intergerrimus & 13 & 8 & 10 & 8 & 8 & 8 \\
\hline 11. & 11.0 & Scrub oak (tree) & Q. dumosa & 10 & 10 & 11 & 11 & 11 & 13 \\
\hline 12. & 11.5 & Madrone & Arbutus menziesii & 6 & 13 & 13 & 13 & 12 & 12 \\
\hline 13. & 14.0 & Live oak (shrub) & Q. wislizenii & - & - & - & - & - & 14 \\
\hline 14. & 14.3 & Scrub oak (shrub) & $Q$. dumosa & 9 & 11 & 12 & 15 & 19 & 20 \\
\hline 15 . & 15.0 & Chamise & Adenostoma fascuculatum & 15 & 17 & 15 & 14 & 14 & 15 \\
\hline 16. & 15.0 & Live oak (tree) & Q. wislizenii & 20 & 20 & 14 & 12 & 13 & 11 \\
\hline 17. & 15.2 & Buck brush & C. cuneatus & 11 & 12 & 19 & 16 & 15 & 18 \\
\hline 18. & 15.2 & Common manzanita & Arctostaphylos manzanita & un & un & 16 & 17 & 16 & 16 \\
\hline 19. & 18.8 & Leather oak & Q. durata & 12 & 19 & 20 & 20 & 20 & 22 \\
\hline 20. & 20.7 & Wavyleaf ceanothus & C. foliosus & 17 & 15 & 21 & 22 & 24 & 25 \\
\hline 21. & 20.8 & Chaparral pea & Pickeringia montana & 14 & 18 & 23 & 23 & 23 & 24 \\
\hline 22. & 21.7 & California red berry & Rhamnus crocea & 16 & 16 & 22 & 24 & 25 & 27 \\
\hline 23. & 22.0 & Eastwood manzanita & A. glandulosa & un & un & 18 & 18 & 17 & 17 \\
\hline 24. & 22.5 & Hoary manzanita & $A$ canescens & un & un & 17 & 19 & 18 & 19 \\
\hline $25:$ & 25.5 & Toyon & Photinia arbutifolia & un & un & 24 & 25 & 21 & 21 \\
\hline 26. & 25.5 & Silk tassel & Garrya fremontii & un & un & 25 & 21 & 22 & 23 \\
\hline 27. & 27.3 & California bay & Umbellularia californica & 21 & 21 & un & un & un & 29 \\
\hline 28. & 30.2 & Yerba santa & Eriodictyon californicum & un & un & un & un & un & 26 \\
\hline 29. & 30.5 & Pitcher sage & Lepechinia calycina & un & un & un & un & un & 28 \\
\hline 30. & 31.0 & Nutmeg & Torreya californica & un & un & un & un & un & un \\
\hline 31. & 31.0 & Cypress & Cupressus sargentii & un & un & un & un & un & un \\
\hline
\end{tabular}

* Lichen is classed as a forb in Tables $9,10,12,13$, and 14 but is included here because it grows on oak trees.

$\mathrm{t}-$ (not tested in feeding trials); un (unpalatable - all unpalatable monthly rankings were rated at 31 in determining the average ranking).

When a forage plant was identified in a rumen sample but comprised less than 1 percent of the volume, it was listed as a trace item. Therefore, the calculations of percentages by volume only include those species that contribute 1 percent or more. The frequency calculations, however, include all recorded occurrences. The percentages were rounded to the nearest tenth of a percent. The order of importance was based first on the descending sequence of percentage volumes, and secondly, for those species which had less than 0.1 percent of volume, in descending order of their respective percentage frequencies.

Deer sample data from the Hopland Field Station and the adjacent portion of the Cow Mountain Recreational Area, which some of them frequent seasonally, are summarized in table 8. However, because of the localized nature of the home ranges of these deer, it was possible to further subdivide the data by the cover type (oak woodland or chaparral) from which they were collected (tables 11 and 12). For those deer which were collected along the ecotone between these cover types, data are summarized separately in table 13 . Since sheep movement was restricted by pasture fences, and because they were moved periodically from one pasture to another, it was not feasible to separate the sheep data by cover type (table 9), although the areas where they were collected on the station fell primarily in the oak woodland and the ecotone between the oak woodland and chaparral cover types. 
TABLE 5 .

SHEEP BROWSE PREFERENCES DURING FEEDING TRIALS, MAY TO OCTOBER, 1962

\begin{tabular}{|c|c|c|c|c|c|c|c|c|}
\hline \multirow{2}{*}{$\begin{array}{l}\text { Overall } \\
\text { preference } \\
\text { rank }\end{array}$} & \multirow{2}{*}{$\begin{array}{c}\text { Monthly } \\
\text { average } \\
\text { rank }\end{array}$} & \multirow{2}{*}{ Common name* } & \multicolumn{6}{|c|}{ Monthly rank $†$} \\
\hline & & & May & June & July & Aug. & Sept. & Oct. \\
\hline 1. & 2.0 & Black oak & 2 & 1 & 2 & 2 & 3 & 2 \\
\hline 2. & 3.3 & Mistletoe & 5 & 2 & 3 & 5 & 4 & 1 \\
\hline 3. & 3.8 & Lichen & 6 & 5 & 1 & 1 & 1 & 9 \\
\hline 4. & 4.3 & Poison Oak & 3 & 7 & 4 & 3 & 2 & 7 \\
\hline 5. & 5.3 & Valley oak & 4 & 4 & 5 & 8 & 8 & 3 \\
\hline 6. & 6.5 & Blue oak & 1 & 3 & 9 & 9 & 9 & 8 \\
\hline 7. & 7.7 & Elderberry & 10 & 11 & 8 & 6 & 6 & 5 \\
\hline 8. & 7.7 & Buckeye & 19 & 8 & 6 & 4 & 5 & 4 \\
\hline 9. & 8.5 & Mt. mahogany & 14 & 6 & 7 & 7 & 7 & 10 \\
\hline 10. & 9.3 & Madrone & 11 & 9 & 10 & 10 & 10 & 6 \\
\hline 11. & 12.3 & Chamise & 7 & 12 & 12 & 12 & 15 & 16 \\
\hline 12. & 12.5 & Live oak (tree) & 17 & 10 & 11 & 13 & 13 & 11 \\
\hline 13. & 12.7 & Sweet birch & 8 & 13 & 13 & 11 & 11 & 20 \\
\hline 14. & 14.0 & Scrub oak (tree) & 12 & 14 & 15 & 15 & 14 & 14 \\
\hline 15. & 16.3 & Buck brush & 9 & 18 & 17 & 18 & 17 & 19 \\
\hline 16. & 17.0 & Common manzanita & 25 & 24 & 14 & 14 & 12 & 13 \\
\hline 17. & 17.0 & Live oak (shrub) & - & - & - & - & - & 17 \\
\hline 18. & 18.3 & Yerba santa & 26 & 20 & 16 & 17 & 16 & 15 \\
\hline 19. & 18.4 & Leather oak & - & 16 & 18 & 16 & 18 & 24 \\
\hline 20. & 18.5 & Toyon & 21 & 19 & 20 & 20 & 19 & 12 \\
\hline 21. & 19.5 & Scrub oak (shrub) & 13 & 15 & 19 & 21 & 23 & 26 \\
\hline 22. & 22.0 & Silk tassel & 23 & 26 & 26 & 19 & 20 & 18 \\
\hline 23. & 22.3 & Eastwood manzanita & 24 & - & - & 23 & 21 & 21 \\
\hline 24. & 22.5 & Hoary manzanita & 22 & 25 & 24 & 22 & 22 & 22 \\
\hline 25 . & 22.7 & California bay & 20 & 21 & 22 & 24 & 24 & 25 \\
\hline 26. & 23.0 & California red berry & 15 & 17 & 25 & 25 & 25 & un \\
\hline 27. & 23.3 & Wavyleaf ceanothus & 16 & 22 & 21 & 26 & 27 & 28 \\
\hline 28. & 24.0 & Chaparral pea & 18 & 23 & 23 & 27 & 26 & 27 \\
\hline 29. & 29.0 & Pitcher sage & un & un & 27 & un & un & 23 \\
\hline 30. & 29.5 & Cypress & un & 28 & 28 & 28 & un & un \\
\hline 31. & 29.7 & Nutmeg & 27 & 27 & un & un & un & un \\
\hline
\end{tabular}

"Latin names given in table 4 .

$\mp-($ not tested in feeding trials); un (unpalatable).

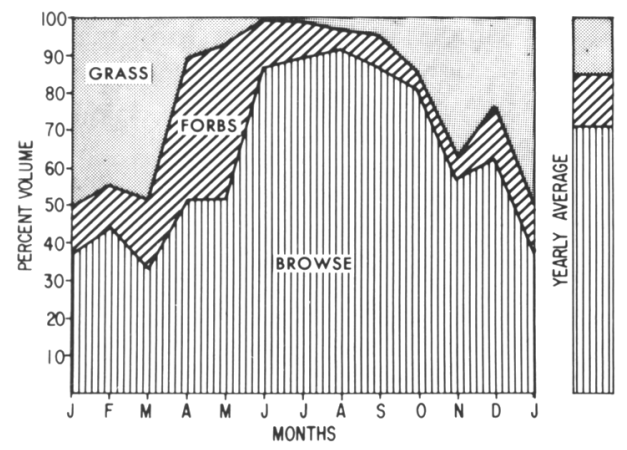

Fig. 3. Percent volume of food based on rumen sample analysis (all deer). Hopland Field Station.

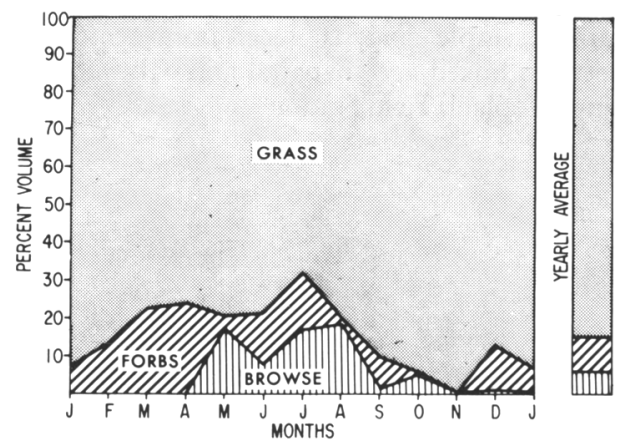

Fig. 4. Percent volume of food based on rumen sample analysis (all sheep). Hopland Field Station. 


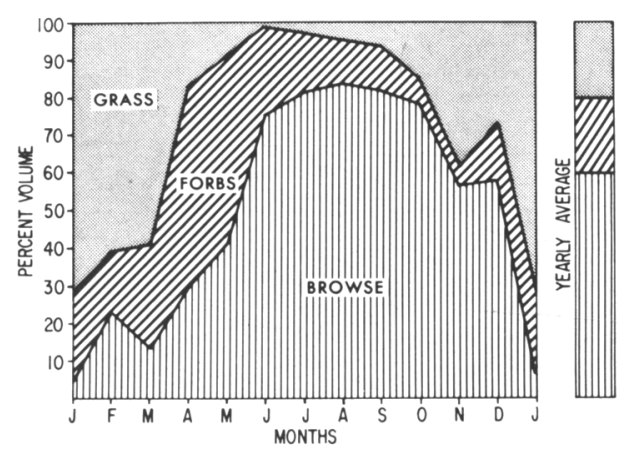

Fig. 5. Percent volume of food based on rumen sample analysis. Deer from oak woodland, Hopland Field Station.

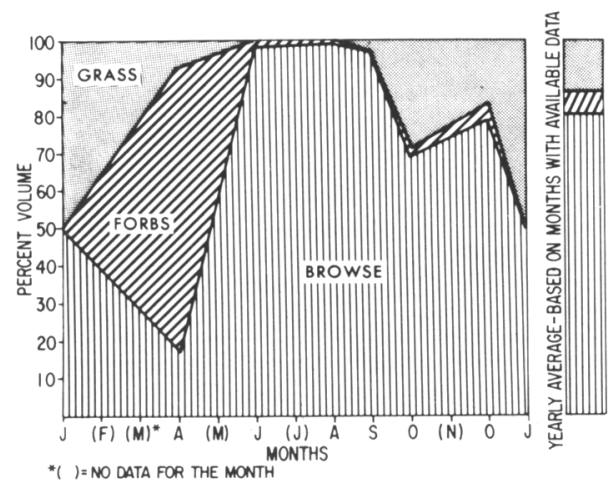

Fig. 7. Percent volume of food based on rumen sample analysis. Deer from ecotone between mixed-age chaparral and oak woodland, Hopland Field Station.

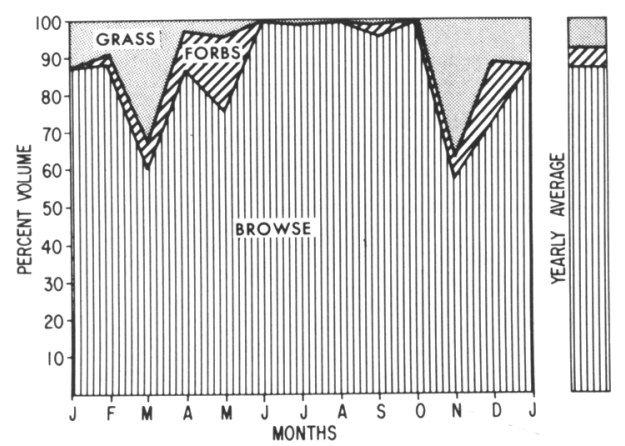

Fig. 6. Percent volume of food based on rumen sample analysis. Deer from mixed-age chaparral, Hopland Field Station and adjacent part of the Cow Mountain Recreation Area.

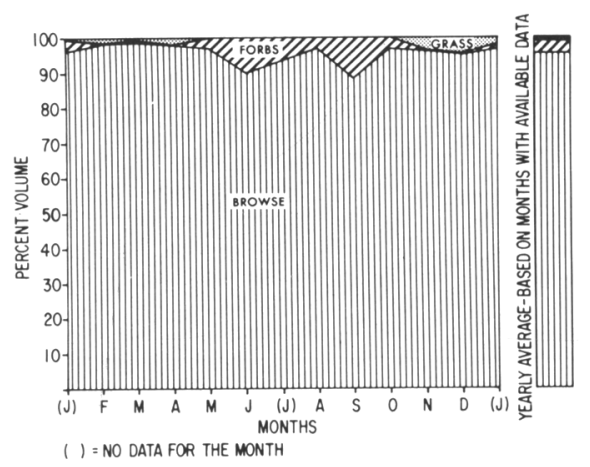

Fig. 8. Percent volume of food based on rumen sample analysis. Deer from mature chaparral, Cow Mountain Recreation Area.

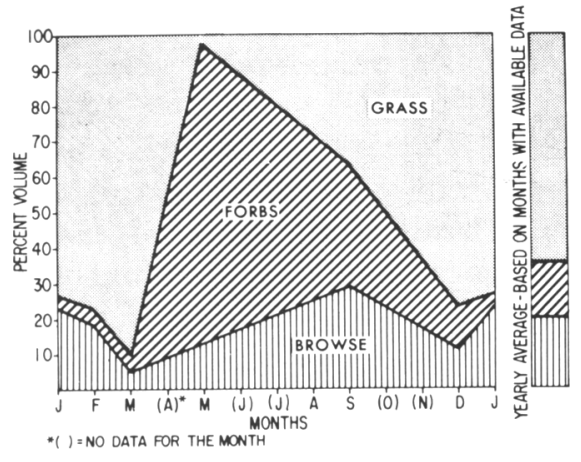

Fig. 9. Percent volume of food based on rumen sample analysis. Deer from Masonite Corporation property. 


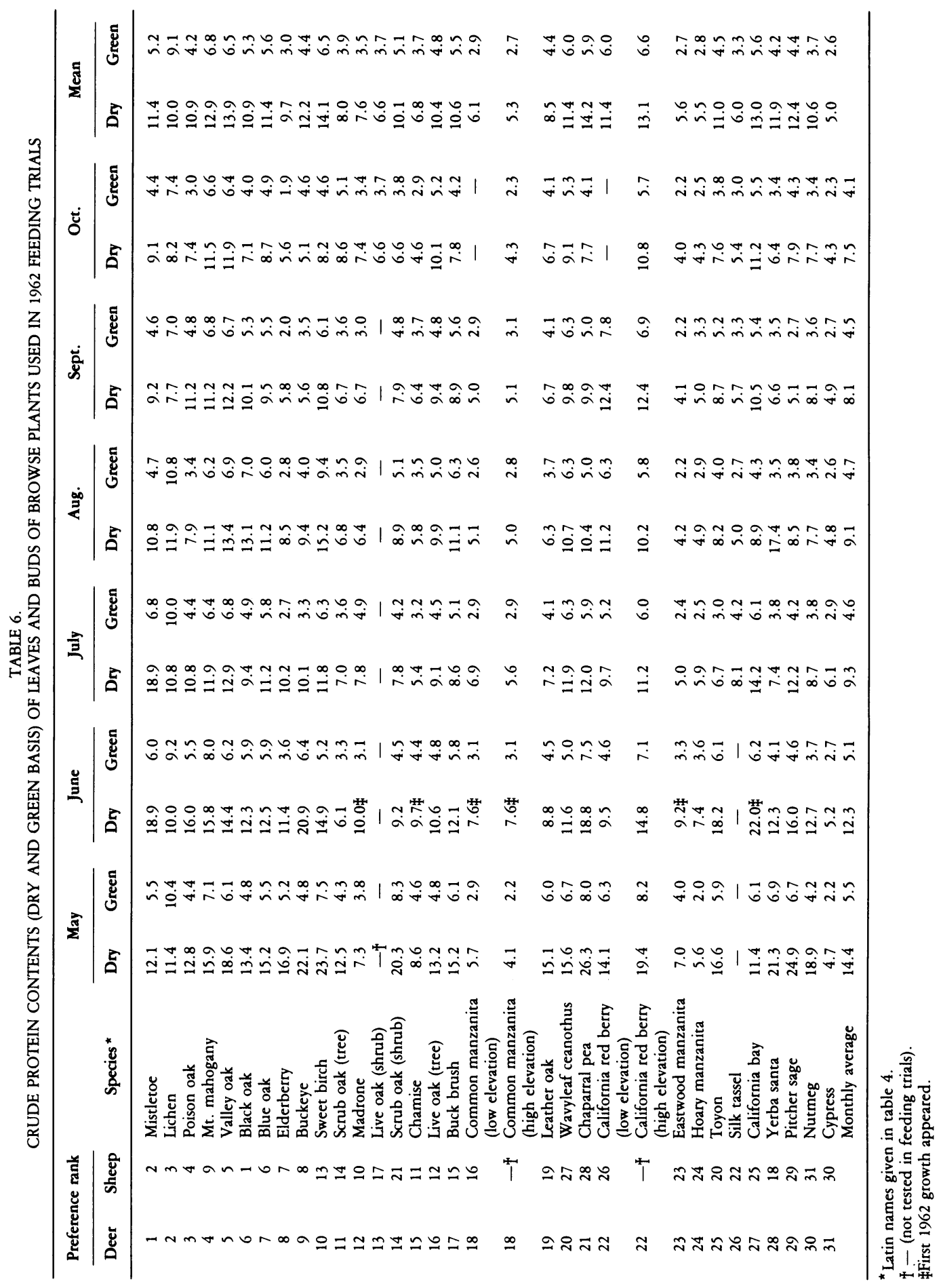


TABLE 7.

TOTAL PHOSPHORUS CONTENT OF SOME BROWSE SPECIES USED IN 1962 FEEDING TRIALS.

\begin{tabular}{|c|c|c|c|c|c|}
\hline \multirow[b]{2}{*}{ Month } & \multirow[b]{2}{*}{ Species ${ }^{\star}$} & \multicolumn{2}{|c|}{ Preference rank } & \multicolumn{2}{|c|}{ ppm phosphorus } \\
\hline & & Deer & Sheep & Dry & Green \\
\hline \multirow[t]{6}{*}{ May } & Black oak & 1 & 2 & 2650 & 950 \\
\hline & Mt. mahogany & 2 & 14 & 2200 & 980 \\
\hline & Chamise & 15 & 7 & 2960 & 1590 \\
\hline & California red berry & 16 & 15 & 2480 & 1100 \\
\hline & Yerba santa & unt & 25 & 2680 & 860 \\
\hline & Common manzanita & un & 24 & 1180 & 640 \\
\hline \multirow{6}{*}{ June } & Lichen & 1 & 5 & 780 & 710 \\
\hline & Mt. mahogany & 2 & 6 & 2010 & 1030 \\
\hline & Chamise & 17 & 12 & 2010 & 920 \\
\hline & California red berry & 16 & 17 & 1990 & 960 \\
\hline & Yerba santa & un & 20 & 2650 & 870 \\
\hline & Pitcher sage & un & un & 3300 & 950 \\
\hline \multirow[t]{6}{*}{ July } & Lichen & 1 & 1 & 1130 & 1050 \\
\hline & Mistletoe & 2 & 3 & 3300 & 1490 \\
\hline & Chamise & 15 & 12 & 2300 & 1360 \\
\hline & Common manzanita & 16 & 14 & 1100 & 580 \\
\hline & Yerba santa & un & 16 & 1330 & 680 \\
\hline & Pitcher sage & un & 27 & 3050 & 1050 \\
\hline \multirow[t]{6}{*}{ August } & Lichen & 1 & 1 & 1330 & 1210 \\
\hline & Poison oak & 2 & 3 & 2300 & 1000 \\
\hline & Chamise & 14 & 12 & 1750 & 1050 \\
\hline & Common manzanita & 17 & 14 & 1250 & 710 \\
\hline & Yerba santa & un & 17 & 1610 & 760 \\
\hline & Pitcher sage & un & un & 1380 & 620 \\
\hline \multirow{6}{*}{ September } & Lichen & 1 & 1 & 730 & 660 \\
\hline & Poison oak & 2 & 2 & 1870 & 800 \\
\hline & Chamise & 14 & 15 & 1050 & 680 \\
\hline & Common manzanita & 16 & 12 & 1100 & 680 \\
\hline & Yerba santa & un & 16 & 1300 & 690 \\
\hline & Pitcher sage & un & un & 2220 & 1190 \\
\hline
\end{tabular}

* Latin names given in table 4 .

t un (unpalatable). 


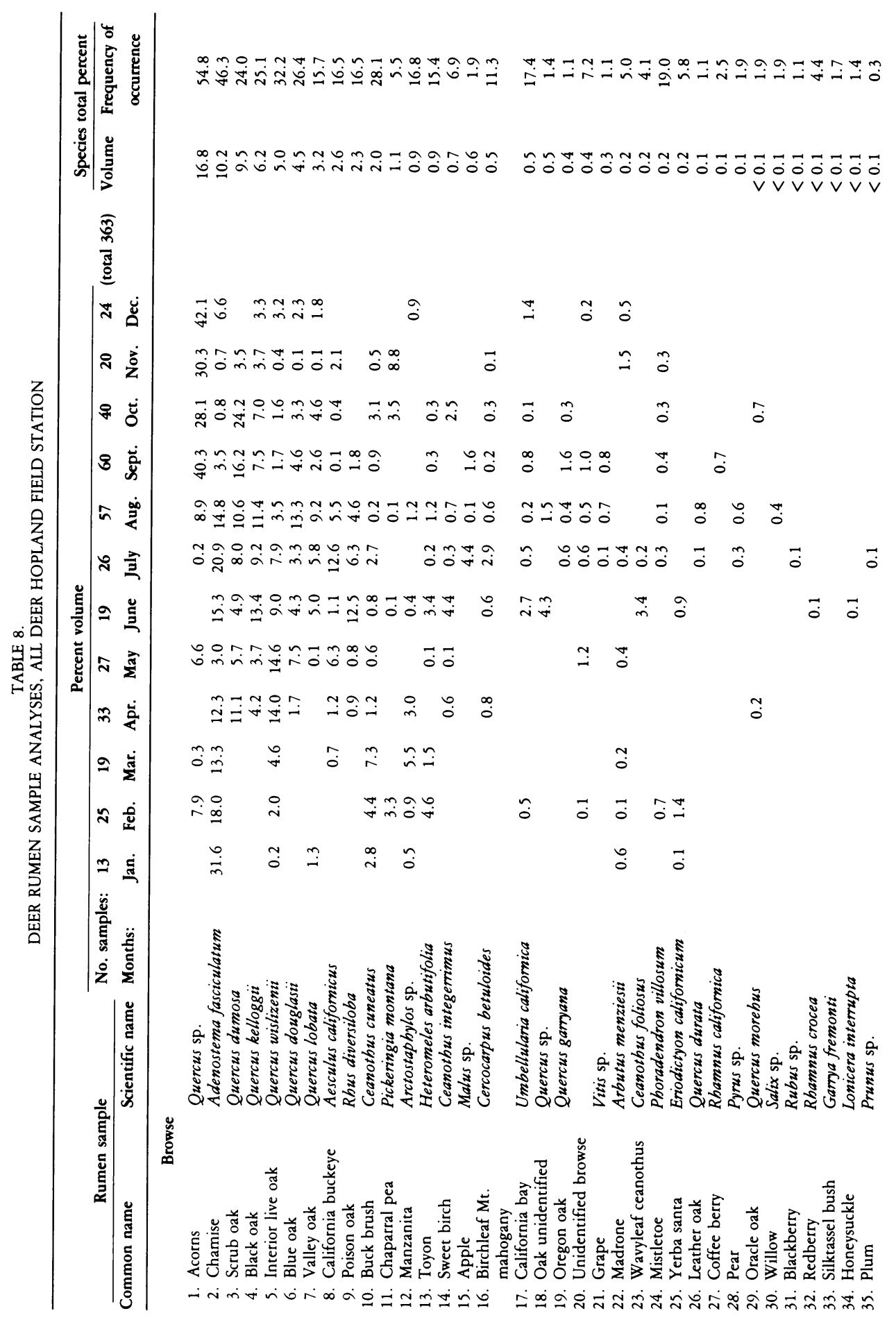




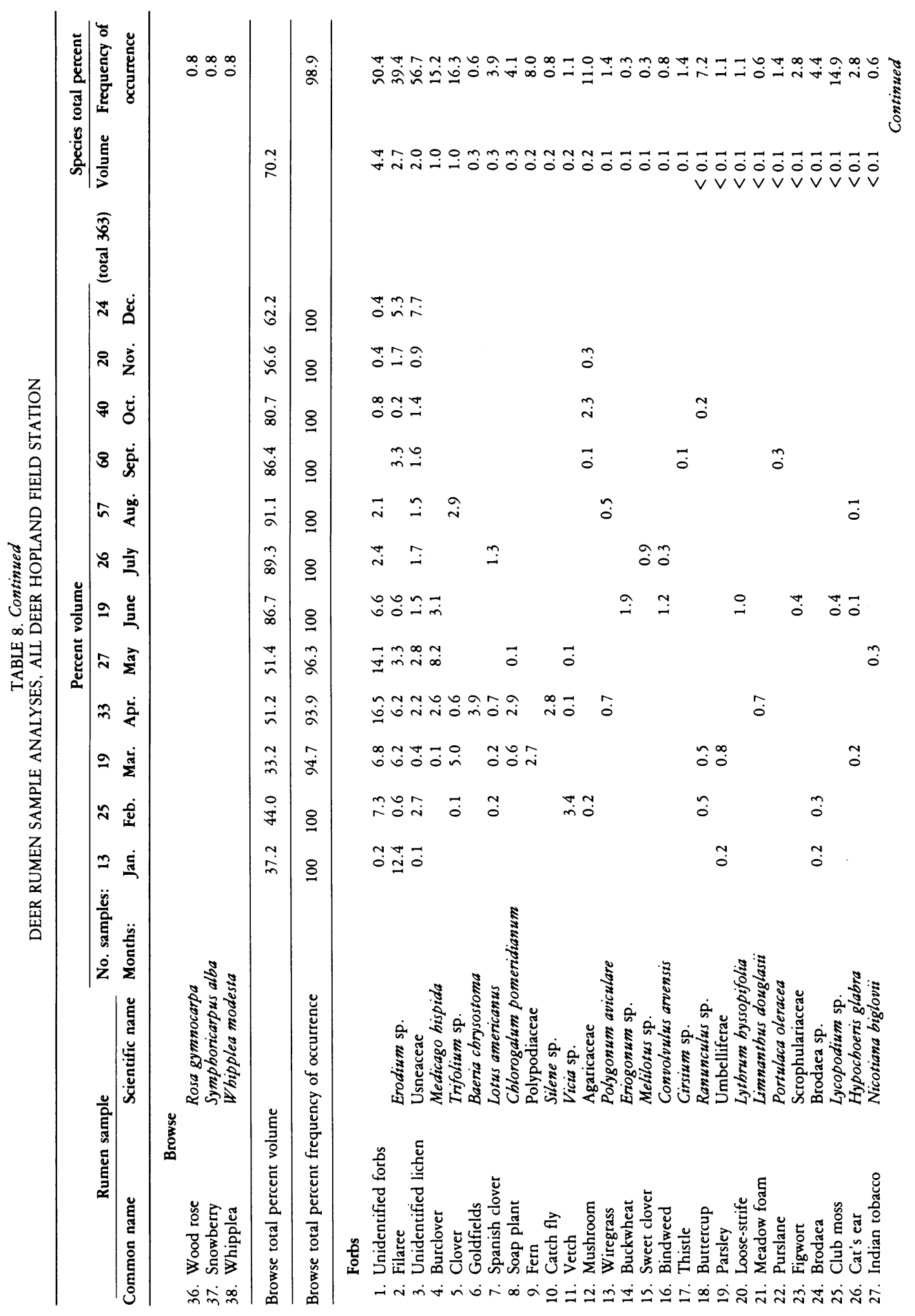




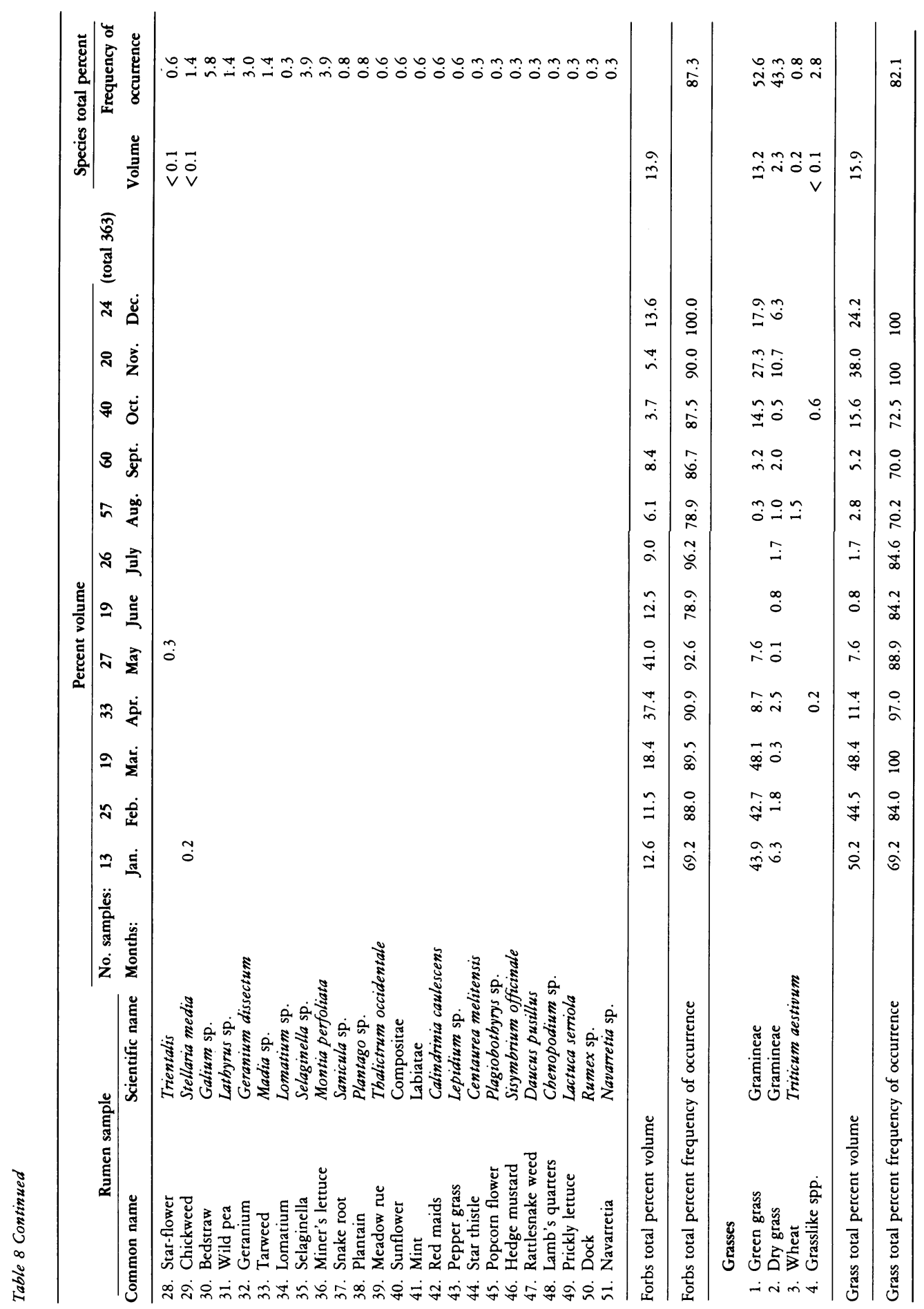




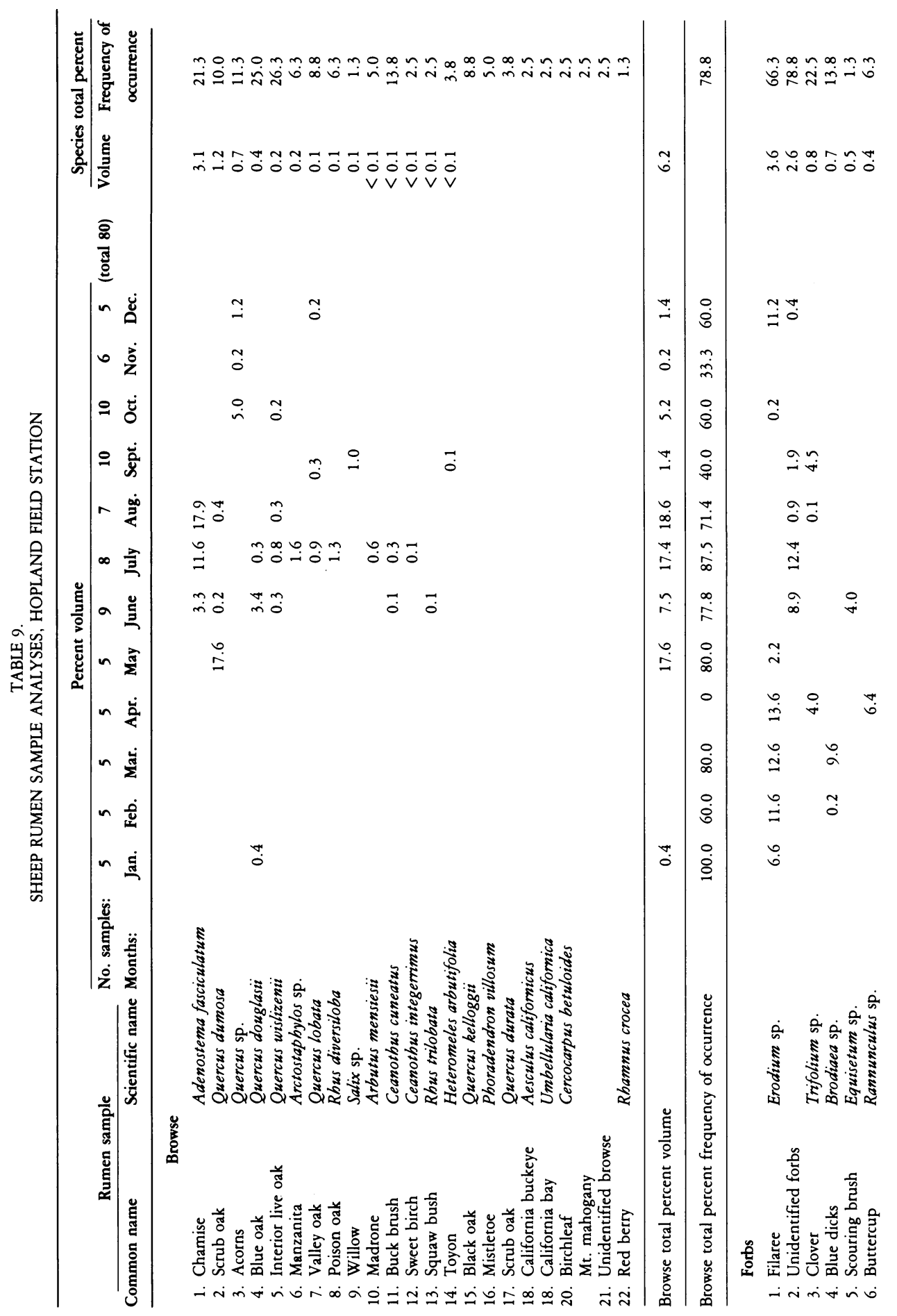




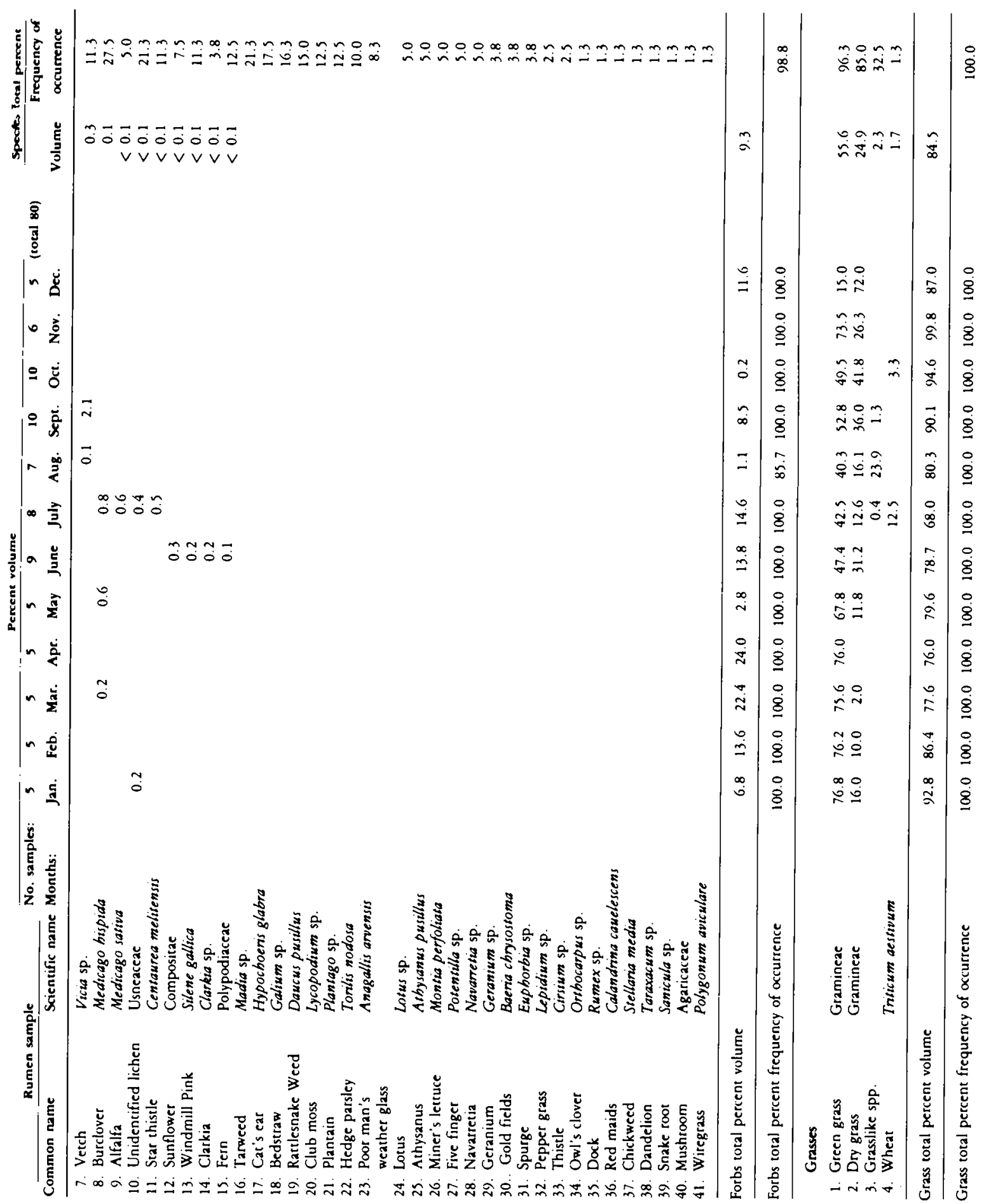



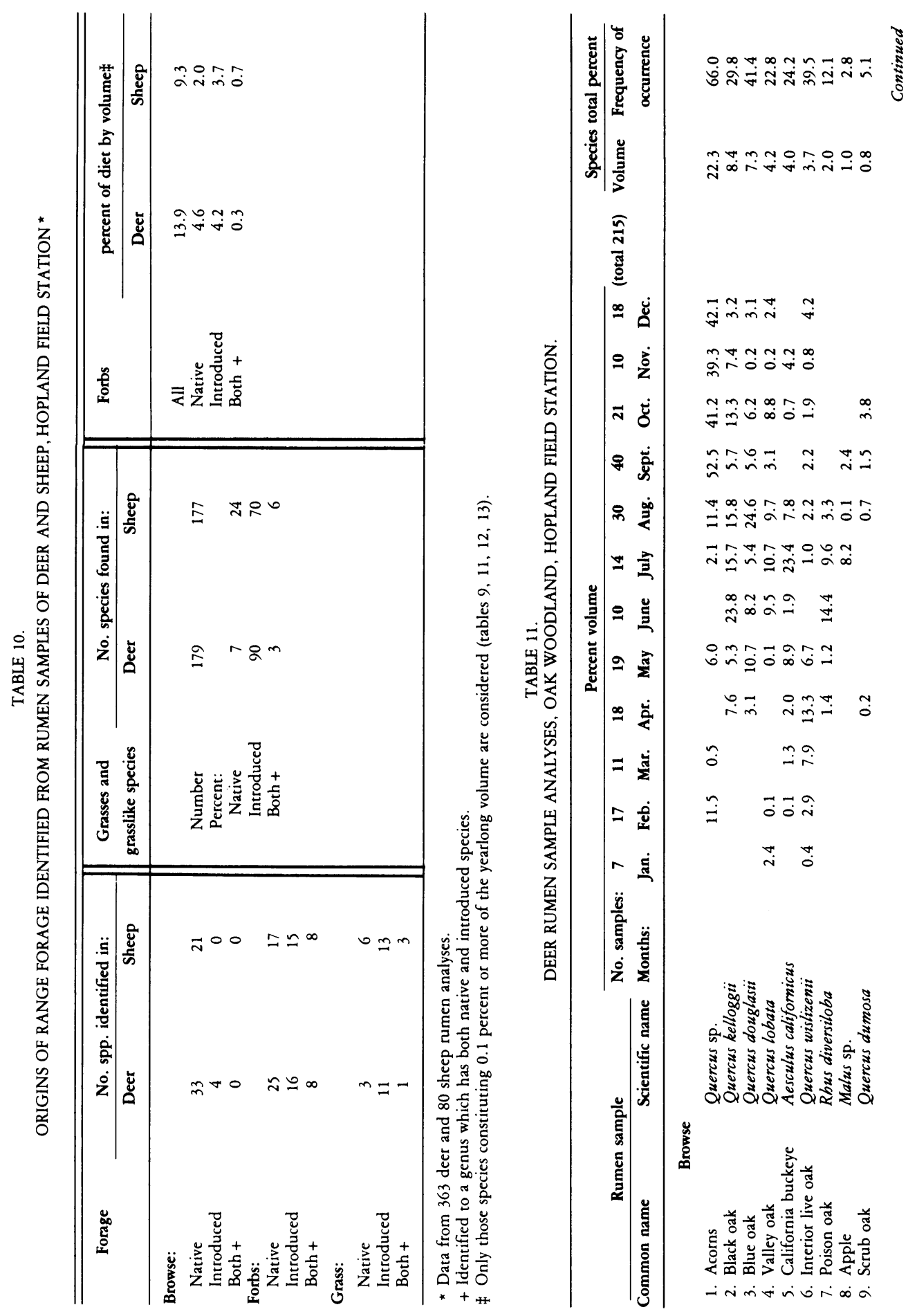


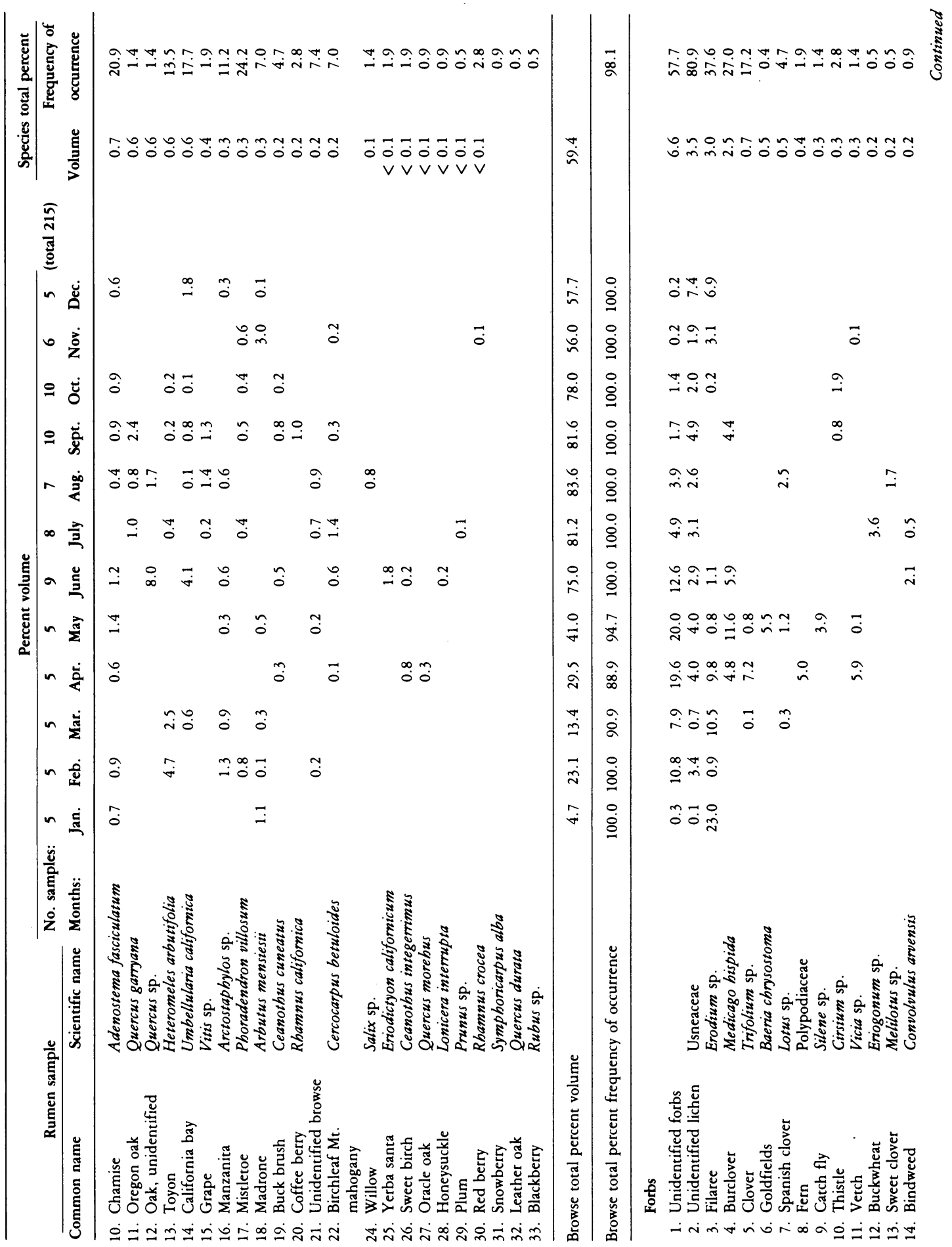




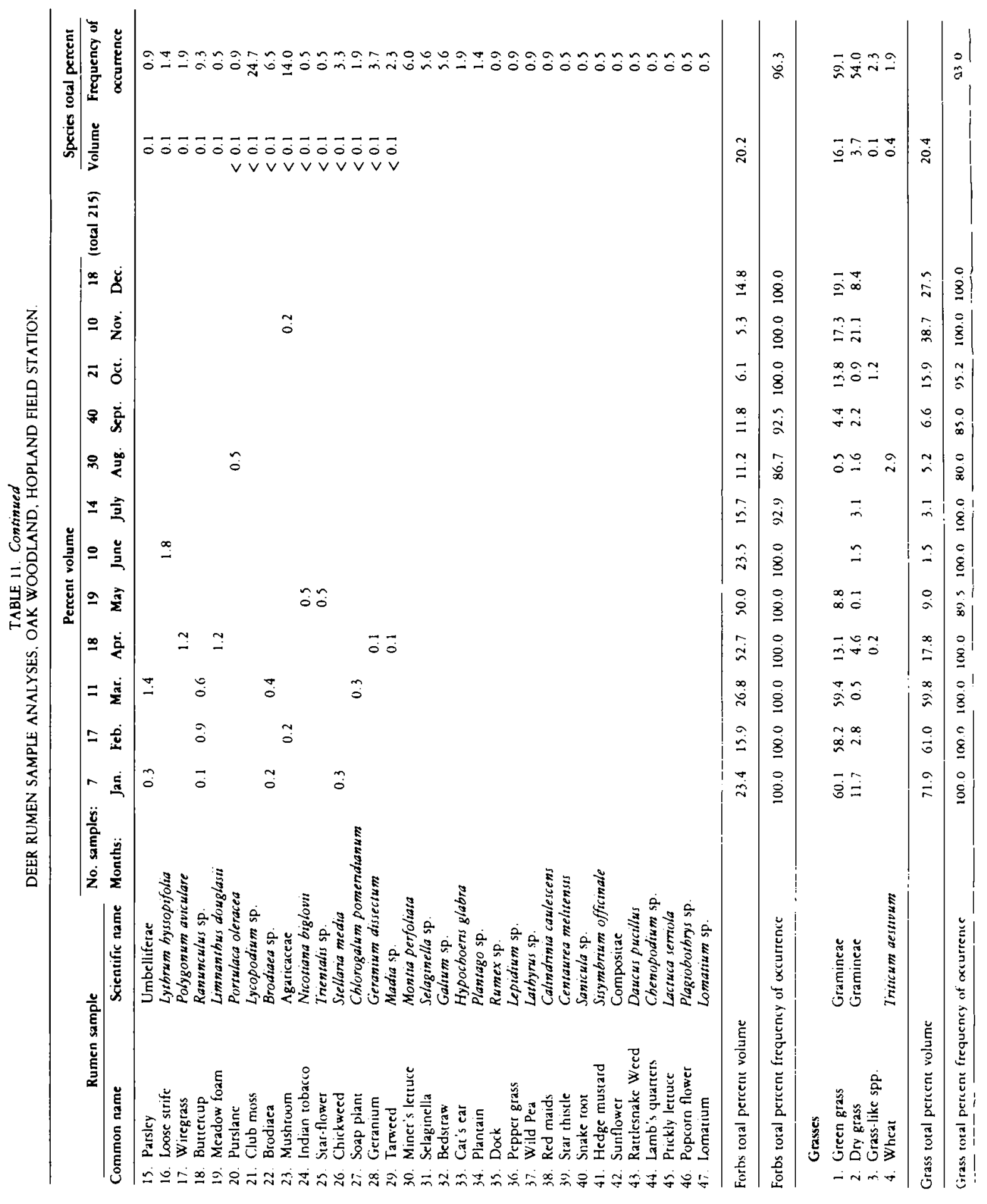




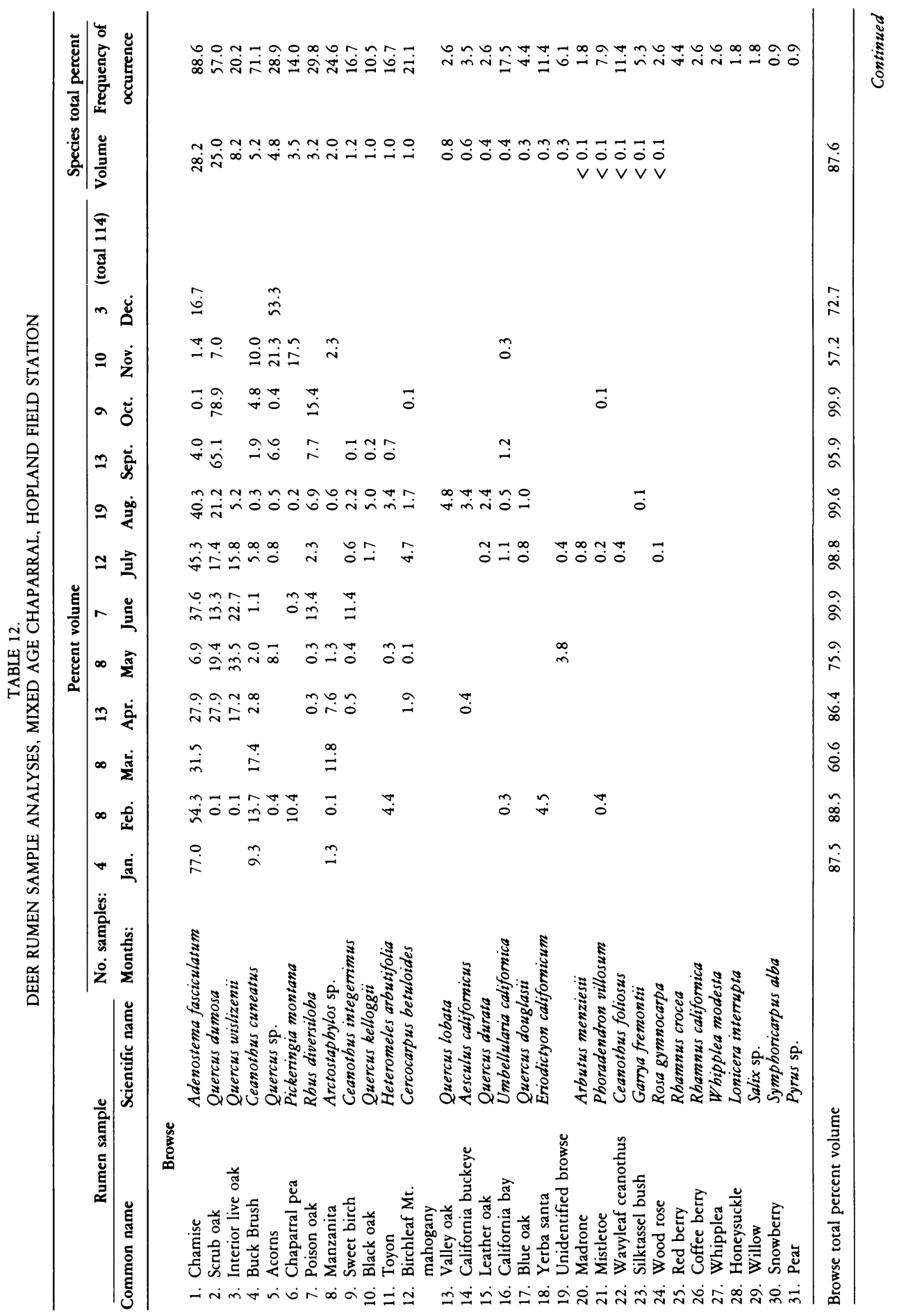




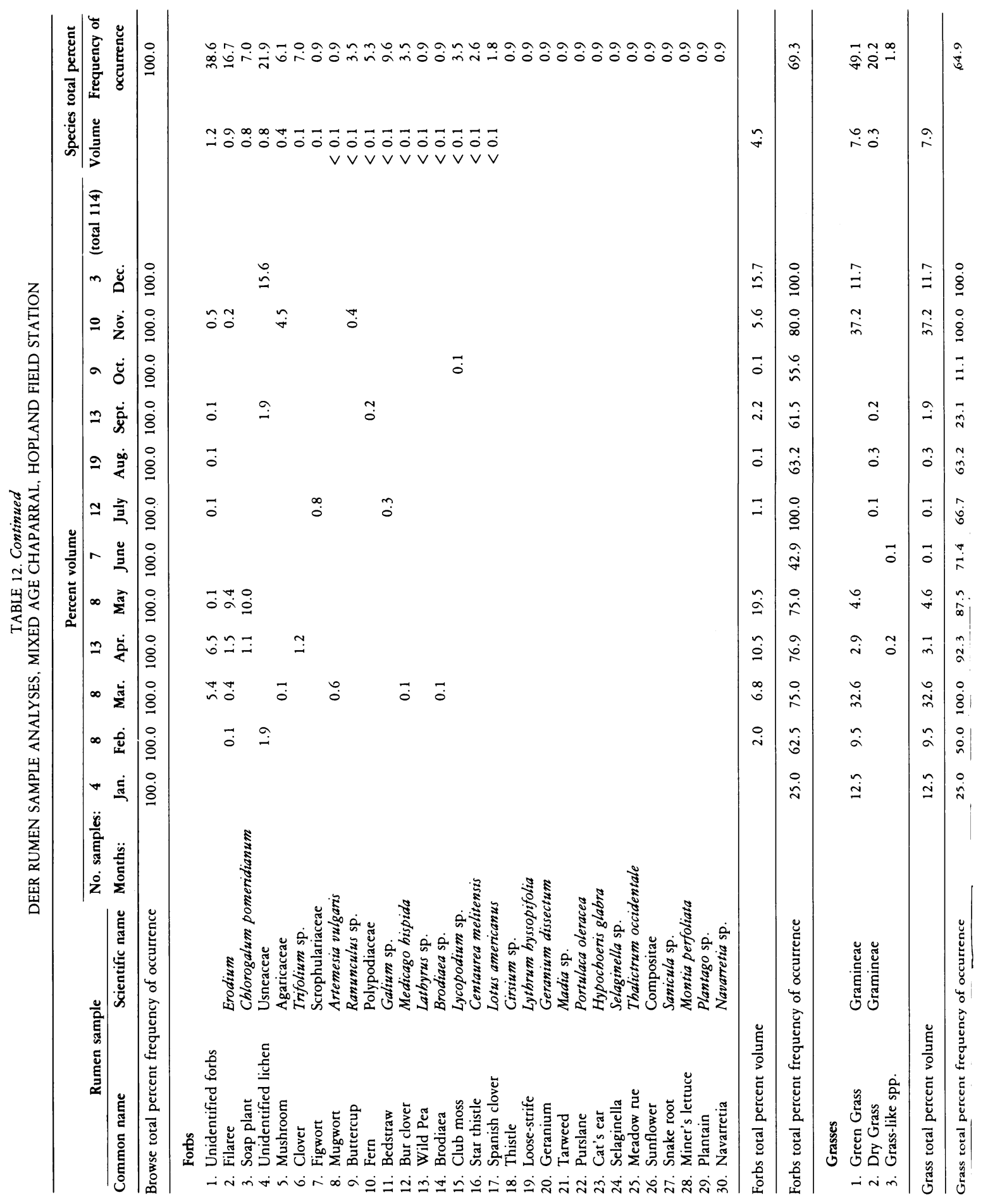




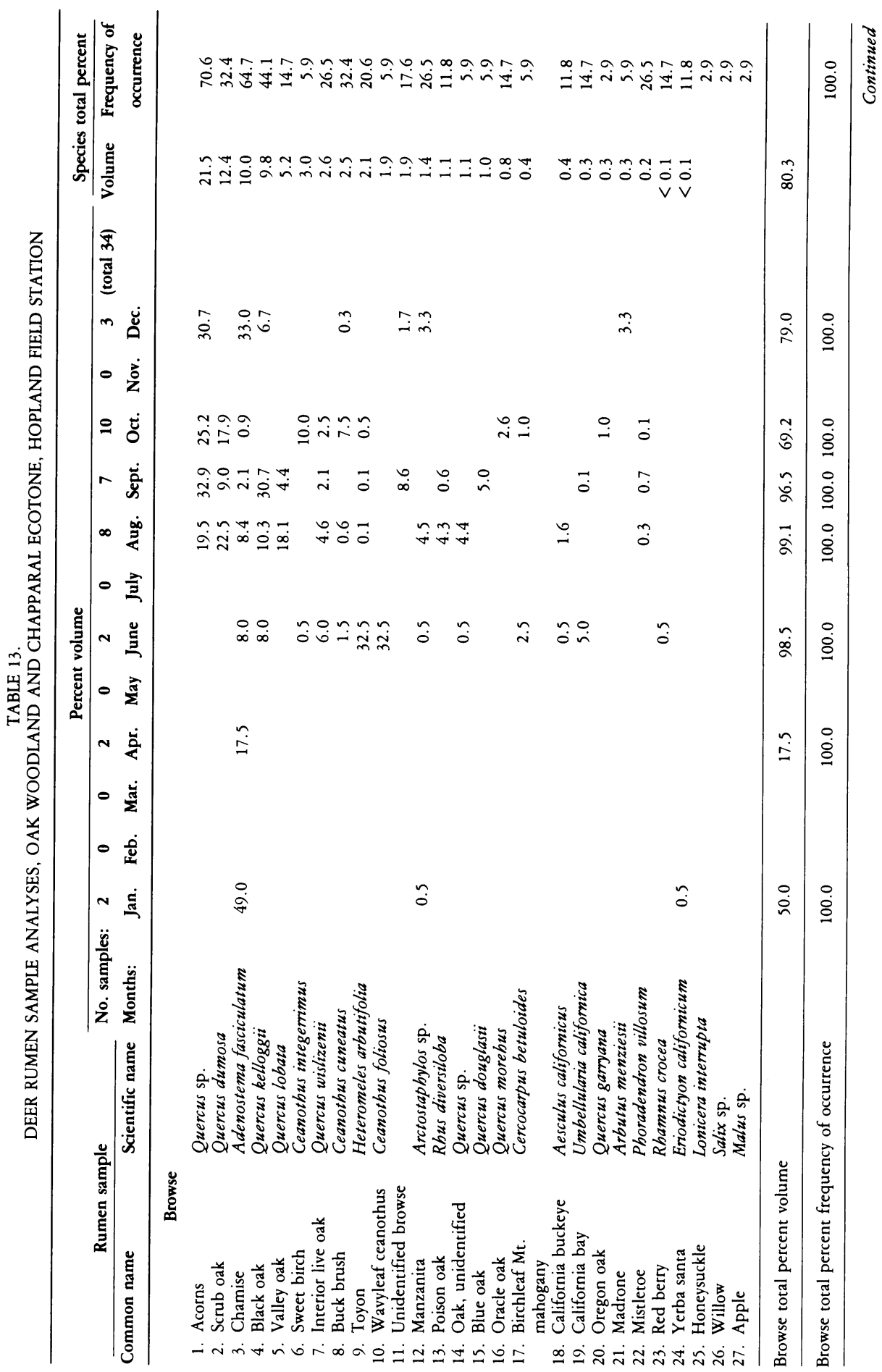




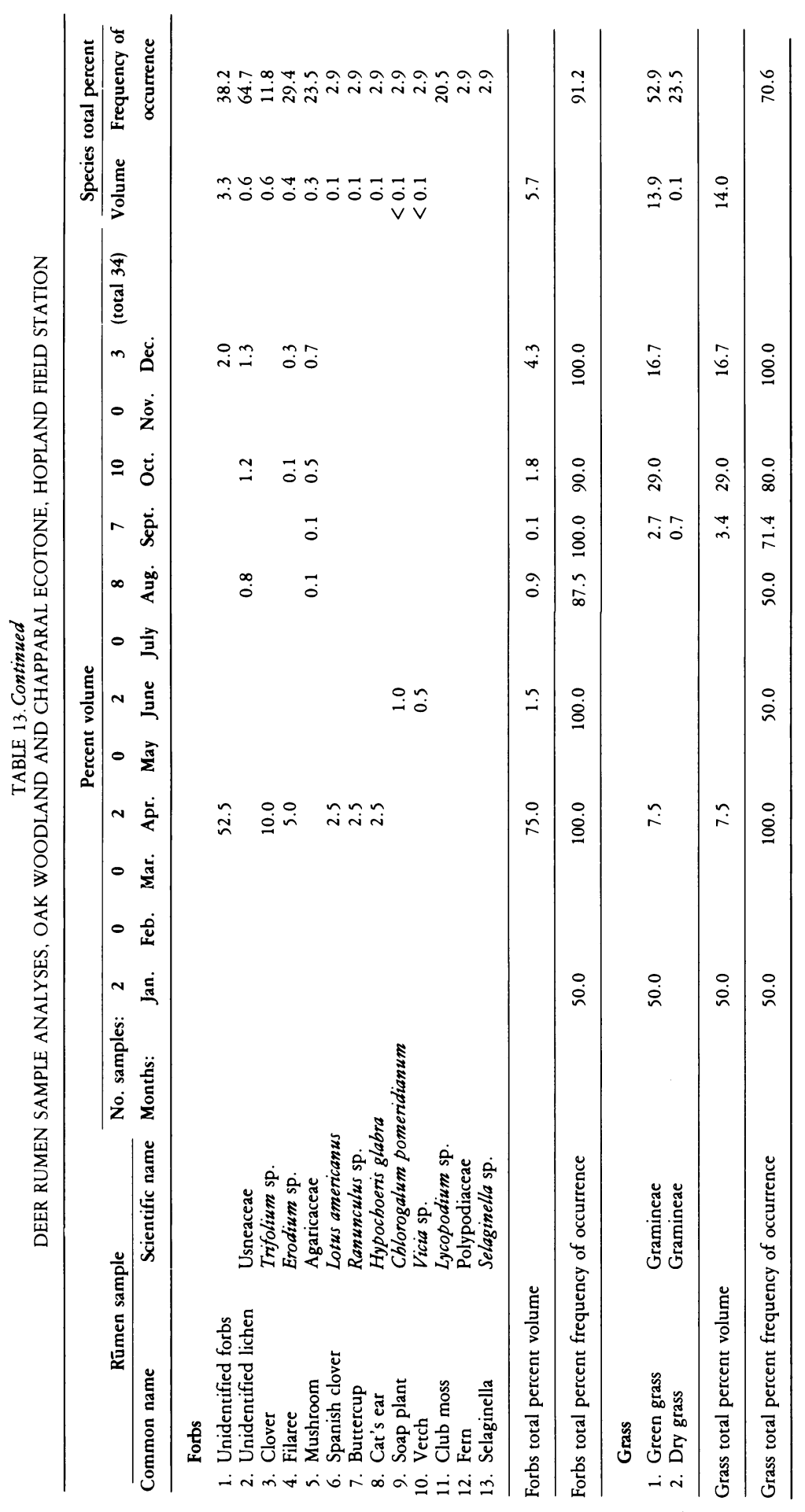




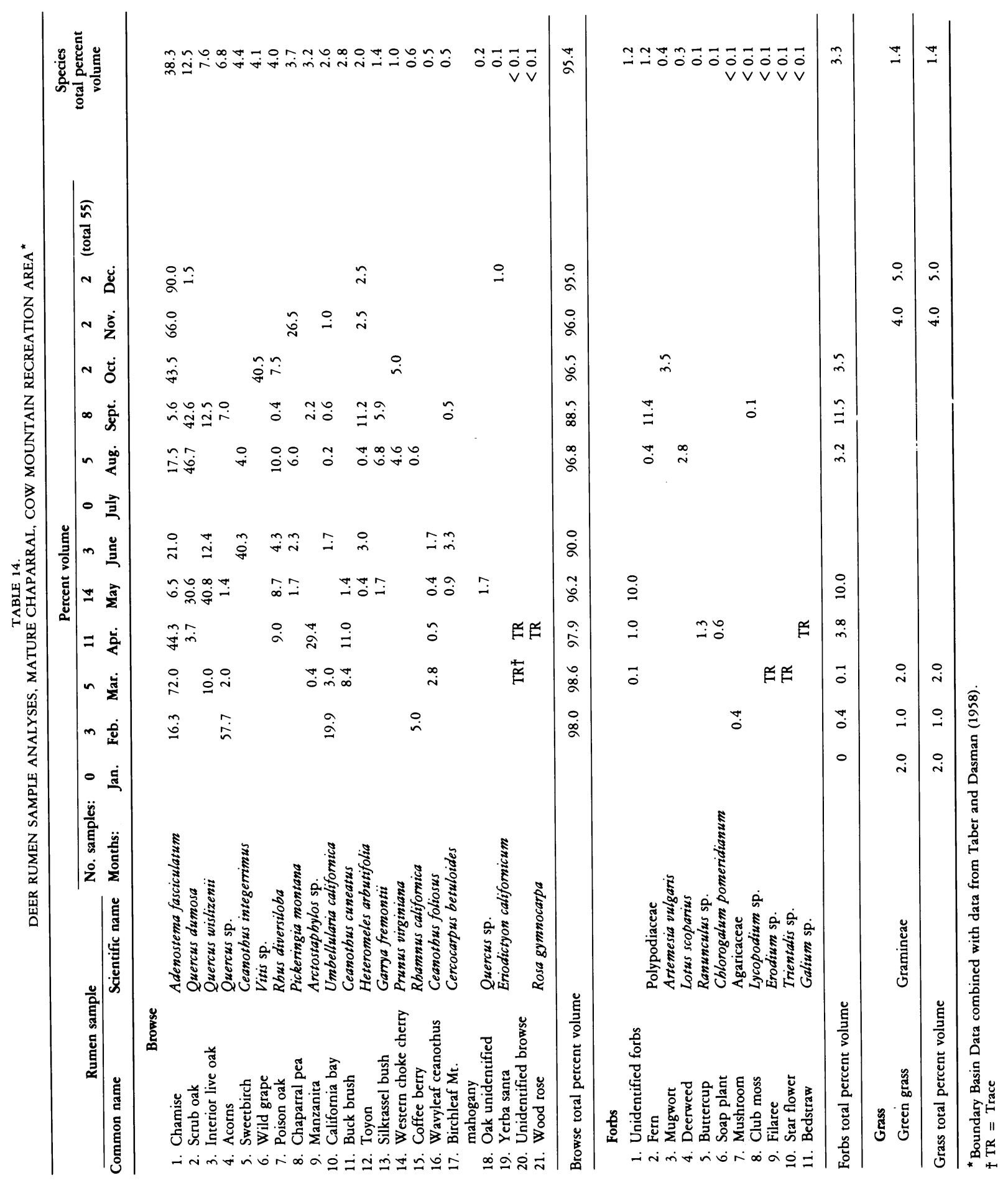




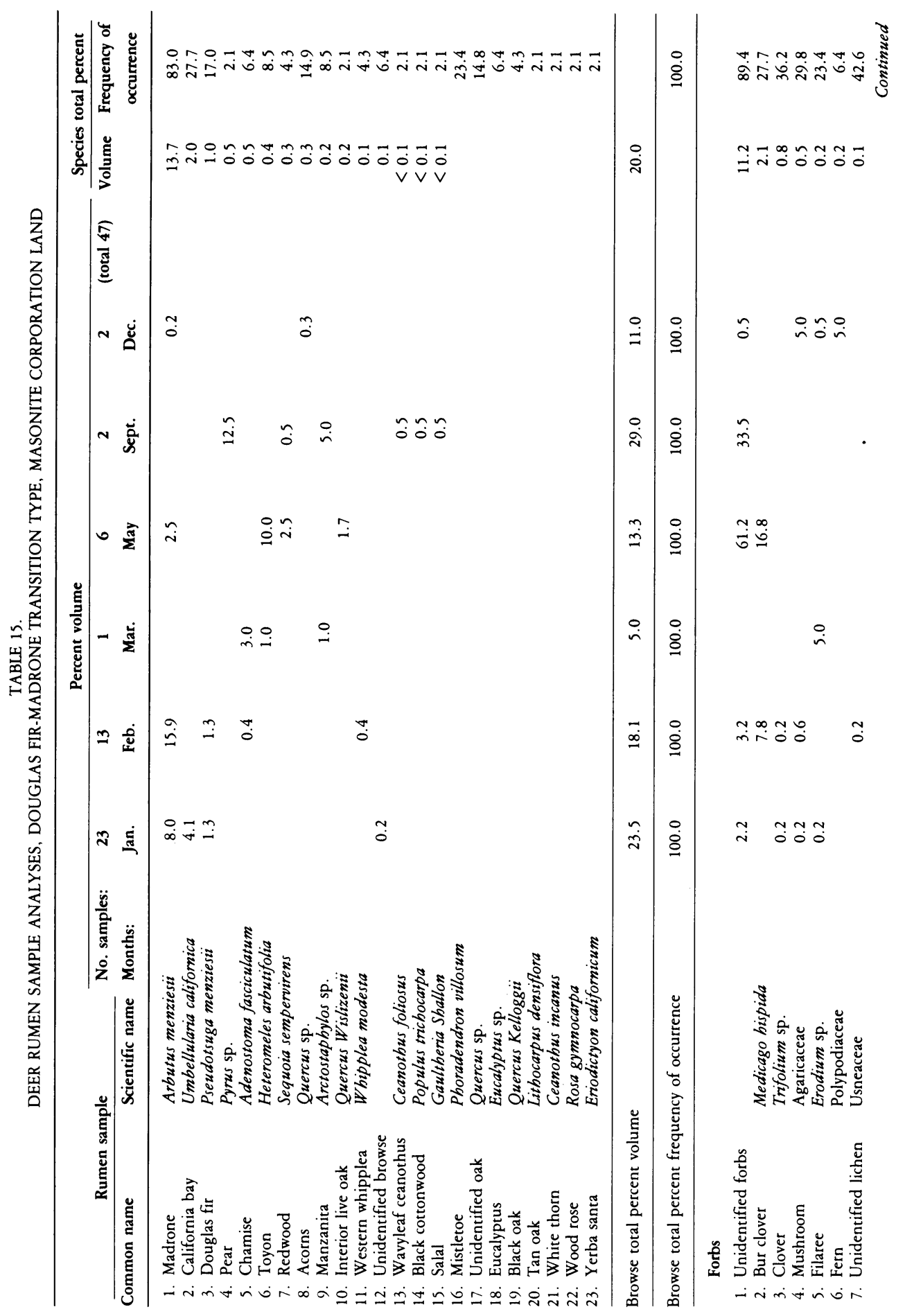




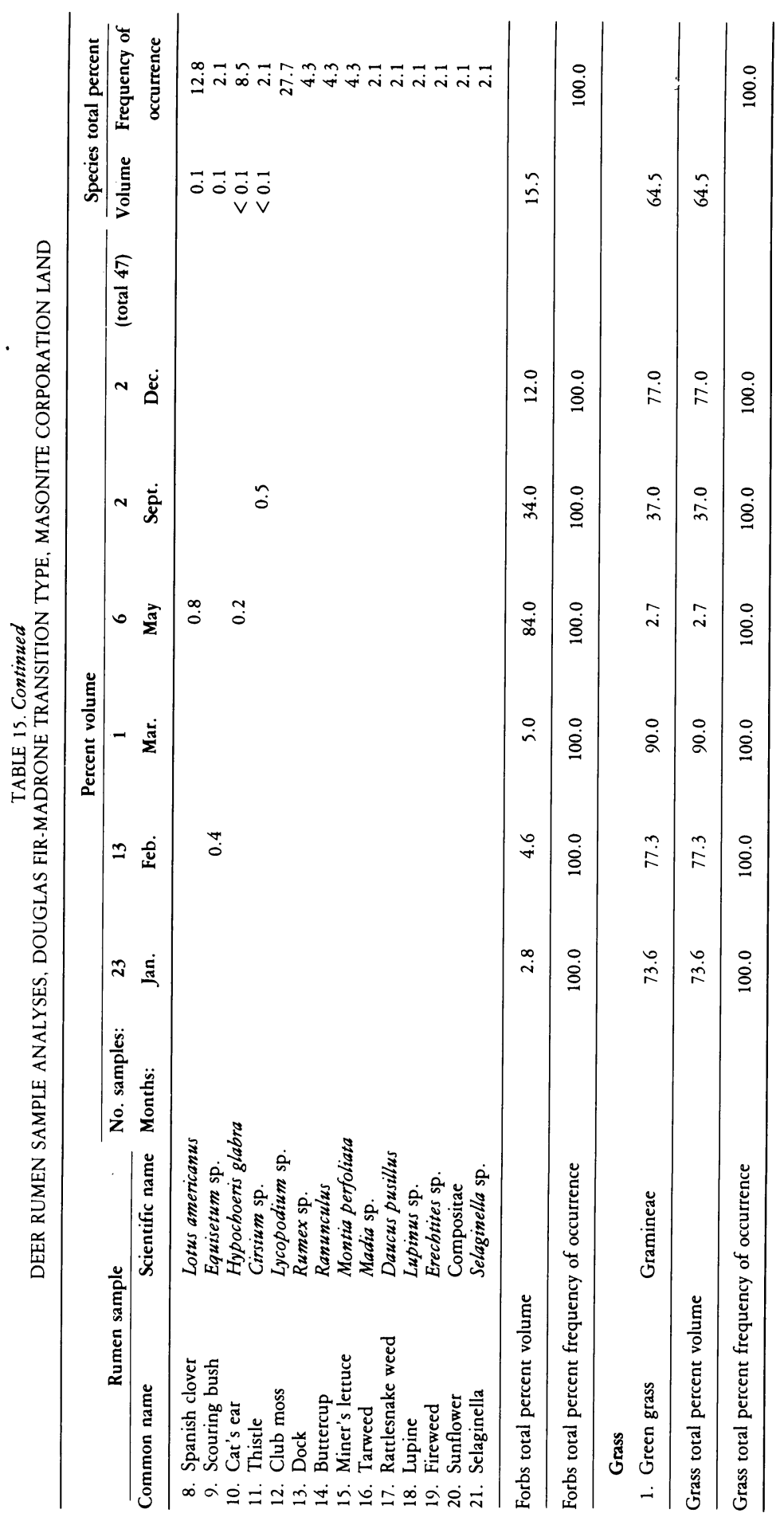




\section{Deer and sheep diet comparison}

Gross comparison of the forage consumed by deer and sheep from oak woodland areas (tables 9 and 11) indicates that deer are much more dependent on browse than are sheep, with browse comprising 59.4 percent versus 6.2 percent of their respective intakes. Deer took 20.2 percent and sheep 9.3 percent of forbs in their diets. The consumption of grass by the two species was essentially the converse of browse intake. Grass or grass-like plants accounted for 20.4 percent of the deer diet, whereas sheep depended heavily upon grass (84.5 percent).

As might be expected, because deer ate much more browse than sheep, they also used a greater number of browse species (33 vs. 22). Twenty-four browse species each contributed 0.1 percent or more to the dietary volume of deer, compared with only nine species used to this extent by sheep.

On a seasonal basis, deer consumed significant amounts of browse every month throughout the year, whereas sheep browsing was primarily confined to the spring, summer, and early fall (May through October), although small or trace amounts of browse were found during the other months. Overall, some browse was found in 98.1 percent of all deer samples examined, and in 78.8 percent of the sheep rumen samples.

It is of interest that of the browse consumed by sheep, oak leaves plus acorns, comprised 42 percent, whereas with deer in the oak woodland type, oak leaves and acorns furnished 81 percent of their browse. In this cover type, sheep were found to take much more chamise (Adenostoma fasciculatum) browse than did deer, and this one species alone amounted to 50 percent of their entire browse intake but only about 1 percent of the deer browse consumption. However, in the oak woodland cover type, deer use of chamise was distributed throughout the year, while sheep only took chamise seasonally in June, July, and August. Also, deer were taking other browse species in greater quantities than sheep during the summer. In contrast, with deer collected in mature chaparral, chamise comprised 38.3 percent of their entire diet and 40 percent of their browse intake.

Deer fed on a greater variety of forb species than did sheep, 47 and 41 , respectively. Nineteen forbs each contributed over 0.1 percent to deer diets, while only eight species were involved to this extent in sheep diets. However, this difference may also be a reflection of the greater number of deer rumen samples examined.

Deer consumed forbs during every month of the year, but heaviest use extended from January through May. April and May were especially important months, when forb consumption was 52.7 percent and 50.0 percent, respectively, of all forage intake. Forbs were found in 96.3 percent of all deer samples and in 98.8 percent of all sheep samples. Sheep samples contained forbs in every month, although only trace amounts were detected in November. Sheep, like deer, also consumed more forbs in the spring, particularly in March and April, when percentages ran to 22.4 and 24.0 respectively.

Since both deer and sheep masticate much of their forage into very small bits, identification of many forbs found in rumen samples was not possible to the species or even the generic level. Therefore, the category of unidentified forbs was important in both animals. In addition to this unidentified category, filaree (Erodium botrys) and clover (Trifolium spp.) ranked high in importance for both deer and sheep. Deer also ate significant amounts of the lichens which grow on oak trees, while sheep selected brodiaea lilies. The arboreal lichens belonged to several genera, including Ramalina, Usnea and Evernia. However, Ramalina reticulata and Usnea sp. were the primary forms identified in rumen samples (Book, Connolly, and Longhurst, 1972).

As with forbs, because of the difficulty of identifying finely masticated grasses to 
species or even genera, grasses were lumped together and only separated on the basis of being green or dry. From the amounts consumed, it is evident that grasses are the primary food for sheep throughout the year. Grass consumption fell below 70 percent of the total volume of sheep rumen samples only during July, and even then it was 68 percent. Sheep were apparently able to find significant amounts of green grass even during the dry summer months and, in total, took approximately twice as much green as dry grass (55.6 vs. 24.9 percent).

Although deer also ate some grass during every month, their consumption during the dry months of May through September was minimal. Even though deer did take some dry grass, especially during November, December, and January, only small amounts were taken at other times. Some dry grass may have been inadvertently consumed while ingesting other food from the ground, such as acorns or low-growing filaree or other forbs during their early growth stages. Other grass-like plants, such as rushes or sedges, were taken somewhat more by sheep than by deer, but were not of much importance for either animal.

Deer took advantage of planted species, particularly fruit trees including apples, pears, and plums, when available. Grapes and wheat were also sought. Sheep were found to be eating wheat and alfalfa, but these were probably mostly portions of the supplements provided them. For the most part, the sheep collected for rumen samples were purposely taken from pastures, where they were not being supplemented. Therefore, supplemental items in the rumen samples do not yield an accurate representation of the entire amounts of supplements which the sheep flock as a whole consumed throughout the year.

\section{Deer and sheep consumption of native and introduced plants}

Table 10 indicates the origins of the range forage plants identified in deer and sheep rumen samples. These data show that almost all browse species consumed in the area are native. No introduced browse species were available, except for a few fruit trees at abandoned homesteads on the field station.

In the case of forbs, however, both animals consumed a mixture of native and introduced species, although deer appeared to eat a somewhat greater variety of native forbs than did sheep. On the other hand, native and introduced forbs had nearly equal volumes in deer rumen samples, but sheep depended more on introduced species than native species. Introduced filaree (probably mostly Erodium botrys, tables 9, 11, 12, 13) was the most important forb for both deer and sheep.

It was unfortunate that more grasses could not be identified to species, but the identifications that were possible made it evident that both deer and sheep annually consumed more introduced than native species. Deer were especially dependent upon introduced grasses, apparently selecting them to a greater extent than did sheep. This may reflect the fact that, while introduced species of grass are more palatable and digestible than native species for both deer and sheep, the differences in palatability and digestibility are greater for deer than for sheep (Longhurst et al., 1968).

Among the 179 identifications of grasses made in deer rumen samples, 108 were in the genus Bromus, and of these 72 were $B$. mollis, 12 were $B$. rigidus, while the remaining 24 could only be identified as to genus. Of the 177 identifications of grasses in sheep rumen samples, 62 were in the genus Bromus, and of these, 36 were $B$. mollis, four were $B$. rigidus, one was $B$. rubens and the rest were determined only as to genus. Table 10 details the numbers of grass identifications in deer and sheep rumen samples. 


\section{Deer food habits in relation to cover type}

Deer samples from the field station and the adjacent portion of the Cow Mountain Recreational Area were subdivided into three subgroups according to the cover type where collected. These data are presented in table 11, figure 5 (oak woodland); table 12, figure 6 (burned chaparral); and table 13, figure 7 (oak woodland-chaparral ecotone). Comparing these subgroups, it is apparent that the oak woodland deer consumed a more varied diet than those from the chaparral. Deer from the ecotone between oak woodland and chaparral were intermediate, as might be expected.

Oak woodland deer ate substantially less browse then those in chaparral (59.4 vs. 87.6 percent), although the number of species consumed was very nearly equal (33 compared to 31). In oak woodland, each of 24 species furnished over 0.1 percent or more of the diet, compared with 19 species in chaparral. Acorns were of major importance in oak woodland, furnishing 22.3 percent of the total forage, but they only supplied 4.8 percent in chaparral. Deciduous black, blue, and valley oaks were used heavily in oak woodland, while scrub oak (Quercus dumosa) and the brush form of interior live oak (Q. wislizenii), as well as buck brush (Ceanothus cuneatus), ranked high in chaparral.

Browse was present in all deer rumen samples from both cover types every month of the year. However, browse consumption dropped to relatively low levels in the oak woodland during January, February, and March, when grasses and forbs increased in the diet. No similar seasonal decline in browse utilization was evident in the chaparral, where browse furnished over 60 percent of the diet for all months but November, when it declined to 57.2 percent. Some browse was found in all rumen samples except those collected in oak woodland in March, April, and May, when the respective frequencies declined to $90.9,88.9$, and 94.7 percent.

Forbs constituted a much more important component of the diet of deer in oak woodland than in chaparral areas (20.2 vs. 4.5 percent of total forage volume). Forb variety was also significantly greater in oak woodland, where 19 species contributed over 0.1 percent of the volume compared with only seven species in the chaparral. The total numbers of forb species utilized in oak woodland was 47 , compared with 30 in chaparral.

Grass utilization was similar to forbs in that oak woodland deer consumed much more grass than did those from chaparral (20.2 vs. 7.9 percent). Another contrast of interest is the consumption of dry grass throughout the year by oak woodland deer, while those from chaparral only consumed measurable amounts from July through September. Grass was found in 93 percent of oak woodland rumen samples, compared with 64.9 percent in chaparral.

Deer inhabiting the ecotone between oak woodland and chaparral presumably should be able to take advantage of the wider selection of forage plants available in both cover types compared with either one alone. While sampling of these mixed-cover type deer was not as complete for all months of the year as for oak woodland and chaparral deer, enough were available collectively from the wet and dry seasons to give a general picture of their forage consumption. It was noteworthy that browse utilization by these ecotonal deer was almost identical with those from chaparral (80.3 and 87.6 percent) and was definitely higher than for oak woodland deer (59.4 percent). Browse volume also amounted to 50 percent or more of intake during all months sampled except April, at the height of the forb season, when it dropped to 17.5 percent. Some browse was present in every sample examined from these mixed deer.

The forb component in this group of deer was also very similar to that of chaparral 
deer ( 5.7 and 4.5 percent of the volume of the rumen samples). Oak woodland deer were much higher (20.2 percent). The frequency of forbs in the samples from mixed deer was uniformly high except in January, when only one of the two specimens examined had any traces of forbs. This relatively high frequency of forbs resembled the pattern of oak woodland deer (91.2 and 96.3 percent) more than that of chaparral deer (only 69.3 percent).

Grass percentage in the ecotone deer was almost twice that of deer from chaparral (14.0 and 7.9 percent), but lower than the oak woodland samples which averaged 20.4 percent. Dry grass was only present in trace amounts in the ecotone animals, except for September when 0.7 percent was recorded. The overall frequency of grass from ecotone deer was intermediate between those from chaparral and oak woodland, 70.6, 64.9, and 93 percent, respectively.

\section{Mature chaparral compared with burned chaparral}

The sample of deer from Boundary Basin and the adjacent area on the Cow Mountain Recreation Area afforded a comparison of the deer diet in old, mature chaparral (table 14 , fig. 8) with that in the more recently burned chaparral near the field station (table 12, fig. 6), where fires during the past 30 years have created a mosaic of diversified vegetation.

Because only percent volumes of forage species were available from Taber and Dasmann's 1958 report, percent frequencies of occurrence of forage species are not given in table 14 . However, even with this unavoidable omission, it is possible to evaluate the important differences in the food habits between deer in mature chaparral and those in other cover types.

The most significant feature of the deer rumen samples from mature chaparral is that practically their entire contents are composed of browse. In both mature and mixedage chaparral, browse species are the primary food at all seasons of the year; chamise, scrub oak, and interior live oak are the three most heavily used species. As chaparral matures, fewer species remain usable by deer. In the mature stand, 21 species were identified in the rumen samples, while in the burned chaparral, 31 species were found.

Forbs appear to be restricted in both quantity and variety even in the mixed-age chaparral, but these restrictions are more pronounced in mature chaparral (only 11 species vs. 30 in the mixed aged stand). Likewise, the species consumed in mature chaparral are generally not those which deer seem to prefer where forbs are more abundant, as in oak woodland cover.

Grass also seems to be in short supply, especially in mature chaparral where it is usually restricted to clearings or around springs or roadsides. In fact, grass was only consumed in very small amounts in mature chaparral from November through March when it was green. In mixed-aged chaparral, grass consumption was distributed more evenly throughout the year, evidently a reflection of its greater availability. In the above comparisons, differences in sample sizes may have had some influence on the results.

\section{Douglas fir-madrone transition type, Masonite Corporation land}

Some of the habitat on the Masonite Corporation property northwest of Ukiah is similar to the oak woodland cover type on the field station, although conifer and madrone density is much higher, and understory browse available to deer is much scarcer. The Masonite area is also in a zone of higher precipitation, with rainfall averaging 
1270 to $1524 \mathrm{~mm}$ annually. Vegetation is more typical of the Humid Transition life zone, and such indicator species as redwood (Sequoia sempervirens), tanoak (Lithocarpus densiflorus), madrone (Arbutus menziesii), and salal (Gaultheria shallon) are abundant. Grassland, with its associated forbs, is restricted to the eastern portion of the Masonite area, and even there its distribution is limited. However, grass was abundant in the immediate locale where most of the deer were collected. Portions of the area were logged in the 1950s and have since been replanted to Douglas fir and some eucalyptus.

Only 20.0 percent of the volume of the Masonite deer rumen samples was found to be browse, with 12 species each furnishing 0.1 percent or more (table 15, fig. 9) compared with 24 species in the oak woodland on the field station. Browse was detected in all samples examined and, although the seasonal distribution of samples was not complete, browse consumption only dropped markedly to 5.0 percent of the volume in March. On the other hand, September was the highest browse consumption month but even then intake only amounted to 29.0 percent. Madrone was by far the most heavily used species, furnishing over half the total browse (13.7 percent of rumen sample volume) with bay ranked second (2.0 percent) and Douglas fir third (1.0 percent). Additional browse species not found in samples from the field station or Cow Mountain areas included black cottonwood (Populus trichocarpa), salal, redwood, Douglas fir, and coast white thorn (Ceanothus incanus).

Forbs furnished only 15.5 percent of Masonite rumen sample volume compared with 20.2 percent in the oak woodland on the field station. Nine species supplied 0.1 percent or more, in contrast to 19 species on the field station. Some forbs were found in all Masonite samples examined, however. Only two forbs, lupine (Lupinus spp.) and fireweed (Erichtites spp.), had not been found in the Hopland and Cow Mountain samples. Heaviest use of forbs by Masonite deer was in May and September (84.0 and 34.0 percent of the volume). If more of the spring and summer months had been sampled, it is probable that forb consumption would have been relatively high then as well. Unidentified forbs and bur clover (Medicago hispida) contributed most to volume, with lesser quantities of clover and mushrooms also present.

Grass was by far the most important class of forage for Masonite deer, supplying 64.5 percent of total food volume. Only green grass was found in these samples, but all samples contained some grass. Monthly volumes ranged from a high of 90.0 percent in March to a low of 2.7 percent in May. Since the Masonite area receives more precipitation than the Hopland area and is situated more within the coastal fog zone, it is probable that green grass is more readily available throughout the dry summer months.

\section{Cafeteria feeding trials}

Tables 4 and 5 give deer and sheep browse preference rankings for each month from May through October, the period of greatest browse consumption. The species lists are arranged from most palatable to least palatable, according to their average rank for all 6 months. Table 6 presents results of crude protein analyses of shrubs used in the feeding trials. Samples for analysis were collected as nearly as possible on the first of each month. Table 7 shows total phosphorus content of some of the brush species used in the feeding trials. For these analyses two highly palatable species, two unpalatable species, and two species of medium palatability were selected each month.

It was apparent that a number of factors influenced the preferences shown by deer and sheep. Deer were more active in the morning and evening than at midday, and demonstrated their preferences more clearly before the plant samples wilted. Even with 
palatable species, preference was inversely proportional to the degree of wilting. Deer took palatable browse samples readily even with alfalfa hay and pelleted feed available to them in their pens; but with hay available, sheep paid little attention to browse. It was likewise desirable to keep all brush samples about the same size, for if a larger sample of one species was placed before the animals, they were apt to concentrate on it.

The degree of browsing on plants in the field before they were cut for samples was also of importance, and it was found preferable to select samples from lightly browsed portions of the plants, or from unbrowsed portions above the reach of deer. Only adult does and ewes were used in our cafeteria trials. Supplemental observations of other captive deer, however, showed the does to be somewhat more selective than bucks or fawns in their choice of browse samples. Fawns that were bottle-reared singly in small cubicles (to keep them free of parasites for another study) seemed to have innate browse preferences similar to those shown by fawns that grew up under normal, maternal influence. Sheep generally appeared less selective than deer.

Observations of browse preferences were obviously somewhat subjective, and this was further complicated by the fact that five different observers participated in these trials. We may have misconstrued the exact position of certain species in the preference ranking, but the general position of each species as palatable, moderately palatable, or unpalatable was quite clearly established.

A comparison of tables 4 and 5 shows that the plants generally most preferred by deer are also the most palatable to sheep, and that the least palatable deer browse plants are likewise low in palatability for sheep. Most of the species varied slightly from month to month, with few showing any positive up or down trend during the season. Browse species of low palatability were usually taken more readily by sheep than by deer.

It will be noted that the October preference rank of lichen for both sheep and deer dropped considerably from previous months' levels. This may be associated with a heavy rainfall from October 10 through 14, after which the lichen dried out and was quite stiff and hard. This species was not used in the October trials until about a week after the rain.

The relationships of palatability to protein and phosphorus content of the browse species tested are evaluated in the discussion section. We have not yet established an invariable set of characteristics which determine preference or rejection of forage. Both deer and sheep seem to rely on indicators other than relative nutritional value alone in selecting forage. The deer used in the 1962 trials made initial selections primarily through use of their sense of smell. The usual procedure was for the deer to smell the plant, and then either begin to eat it or shift to another plant. Rarely did a deer refuse a plant after having tasted it. While sheep were observed to smell browse samples before tasting them, this sequence was not nearly as clear-cut as with deer.

On May 11, 1962, an interesting experiment lent weight to the premise that the sense of smell was the primary mechanism involved in forage selection. Essential oils of California bay (Umbellularia californica), a plant consistently low in palatability for deer, were extracted in a steam bath and poured into a bucket of cold water. Then two similar branches of black oak (Quercus kelloggii), high in palatability, were selected. One branch was dipped into the oil-treated cold water, while the other was dipped into untreated cold water. The treated and untreated specimens were offered simultaneously to each of five deer, but only one fawn would eat any of the treated branch. The other deer smelled the treated branch, rejected it, and fed on the untreated specimen. 


\section{DISCUSSION}

\section{Deer compared with sheep}

In examining the diet of deer from the oak woodland cover type, where most of the sheep ranged, it was obvious from the data presented in tables 9 and 11 that deer took a predominantly browse diet ( 59.4 percent), whereas sheep depended primarily on grass ( 84.5 percent) and only to a minor extent on browse ( 6.2 percent). Both animals select certain species of forbs when they are available and are in nutritionally favorable growth stages (deer, 20.2 percent; sheep, 9.3 percent).

Deer also ate a much greater variety of browse and forb species than did sheep, even though significant quantities of both browse and forbs were not identified to the species level in rumen samples from both animals. This difference may partly be a reflection of the fact that deer occupy more diverse habitats than sheep. Here, also, most of the grasses and grass-like species were not identifiable as to species. A separation was made, however, between green and dry grass because these stages of maturity differ in nutritional value.

The general pattern of forage consumption throughout the year can probably best be visualized from figures 4 and 5. Tables 9 and 11 also show how heavily dependent sheep were upon grass the year around in contrast to deer. Sheep also ate significant quantities of dry grass throughout the year except in March and April, when forb consumption was high. Note that sheep ate large amounts of green grass even in the dry summer months when it was in short supply. At that season most of the green grass was probably around spring seep areas or ponds where bermuda grass (Cynodon dactylon) is abundant. However, certain species of native and introduced perennial grasses also produce some green feed during the summer months. At any rate, it is clear that sheep must have made a concerted effort to find green grass in the dry season, when even in the driest months (July, August, and September) it averaged over 45 percent of their diet. Because sheep stocking rates on the station varied from pasture to pasture during the summer months, competition for choice items such as green grass also varied to some extent. However, limitations on the production of green grass were also related to the distribution of spring seeps where bermuda grass was present. Therefore, the above figure (45 percent) represents a composite sample of sheep diets during the dry season, when both competition and availability of green grass varied from pasture to pasture.

The reason for the relatively high intake of dry grass by deer, especially those from oak woodland areas, during November, December, and January is not immediately apparent. It is possible that some dry grass is picked up inadvertently while foraging for green grass and forbs. At this time of year the primary nutritional value which dry grass could furnish for deer is energy, mostly in the form of cellulose, and it is possible that it may fill such a need in these relatively cold months when other energy-rich foods may be in short supply.

As mentioned earlier, it is evident that deer have a much more varied diet throughout the year than do sheep, shifting seasonally to take advantage of changing levels of forage availability and nutritional quality. Sheep follow this pattern to a more limited extent, but do not take advantage of available browse except for small amounts in spring and summer.

Seasonal changes in the kinds of food plants utilized appear to be related mostly to availability and nutritional quality. Most grasses and forbs commence growth following the first germinating rains in the fall, usually in October. However, because of cool 
temperatures through the fall and winter, growth is slow and it is not until temperatures begin to rise, usually in late March and April, that growth accelerates. The growth of these wet-season grasses and forbs usually peaks in late April and early May. Often by mid-May the available moisture in the shallower soils becomes exhausted, and plants growing on such sites are forced to complete their growth cycle, mature, and dry up. Drying of the grasslands is progressive toward the deeper soils and lastly in the wet swales, but in most years, the majority of grasses and forbs have dried up by mid-June.

Perennial species of grass and some forbs, both native and introduced, have a somewhat longer growing season than annual species, and growth usually begins even before the first fall rains. In the spring as well, these species generally still have some green leaves for several weeks after the annual species have dried.

Another group of forbs, of which prickly lettuce (Lactuca seriola) is a good example, have a very different cycle, growing during the summer months. Not all of these summergrowing species are palatable, but those that are, such as prickly lettuce, are avidly sought after by deer and sheep because of the shortage of green, nutritious forage at that season.

The cycle of growth in the woody browse species also differs from that of the grasses and forbs, in that most species are dormant through the winter months and do not commence growing until spring. A few, such as buckeye (Aesculus californicus) and manzanita (Arctostaphylos spp.), start growing as early as February, but most browse growth occurs later, from April through July. By late July or early August, browse growth has generally ceased and the trees and shrubs have become dormant. Most deciduous species tend to retain their leaves until November or December although some species, as, for example, poison oak (Rhus diversiloba) and buckeye, start to lose their leaves earlier, in August and September. Evergreen trees and shrubs retain at least some green leaves throughout the year.

In the area of the Hopland Field Station, there is also a lag in the phenological development of all forage plants that is associated with temperature and altitude. At lower elevations (180 to $250 \mathrm{~m}$ ) growth, especially in the spring, usually commences 4 to 6 weeks earlier than at the cooler upper levels $(900 \mathrm{~m})$.

Since the nutrient content of food plants varies seasonally with the growth stage, and because both deer and sheep attempt to eat the most nutritious forage available, they change their diet, often quite abruptly, when new food supplies become available. Examples of such dietary shifts occur when rapid germination of grasses and forbs follows the first major rains in the fall, or when acorns commence to drop in quantity in August and September.

Acorns produced by the 10 species of oaks growing in the Hopland area are avidly sought after by deer and to a lesser extent by sheep whenever they are available. In the oak woodland cover type, blue oak, black oak, valley oak and interior live oak are the dominant species, while in the chaparral the shrub form of interior live oak and scrub oak are most numerous. Leather oak ( $Q$. durata) is largely confined to serpentine soils within the chaparral. Acorn production varies greatly from year to year for a given oak species, and it is rare for two heavy crops to be produced in sucessive years by the same species. Likewise, it is common for several species, particularly of the deciduous oaks, to be synchronous in their level of acorn production so that variation in total yearly production is thereby accentuated. Despite such variation in acorn abundance, the variety of oaks present assure that some acorns are produced every year, and overall acorn production is much more dependable than in areas with fewer species of oaks.

Blue oaks normally start dropping their acorns in the latter part of August at low eleva- 
tions, followed during September and October by the other species of deciduous oaks. Live oak acorns are usually the last to drop in November and December.

Even though acorns drop from oaks over a limited period, deer were found to consume some acorns in the Hopland area almost throughout the year, and it is probable that with a larger number of rumen samples it would be found that acorns are eaten during all months. As might be expected, acorn consumption was highest during the months of September through December when the drop is heaviest, but if deer can reach them, they will eat acorns directly from trees or shrubby oaks in the chaparral before they drop. Likewise, a sudden spell of hot weather during the spring or early summer may cause a premature drop of undeveloped acorns. Apparently, when acorn production is heavy, there is a carryover of unutilized acorns on the ground for several months after they drop, which would explain consumption in February and March. Acorn use by deer is probably limited primarily by availability.

Although sheep had essentially the same opportunity as deer to feed upon acorns, acorns only made up 0.7 percent of their diet and were taken for a limited period from October through December. Comparatively, acorns composed 22.3 percent of the food eaten by deer in the oak woodland cover type at Hopland.

Because of the extent to which deer depend upon acorns as a source of energy (they have a very high starch content), the major fluctuations in the volume of acorns produced from year to year have significant effects on the deer population. When acorns are abundant in the fall, deer improve in condition and enter the winter with much better reserves of body fat than when acorns are scarce. Exceptionally good acorn years also seem to produce measurable effects on the reproductive success of deer. On the field station since 1952 we have routinely made annual herd composition counts to determine the proportion of bucks, does, and fawns in the population. These counts are made each July, October, and April, and from them it is possible to follow the survival of each cohort of fawns (born from late April to early June) through their first year. In other words, fawns born in the spring of one year would become yearlings the following spring, so that April counts would represent the net survival of fawns born the previous year.

In the section covering the status of deer and sheep we noted that about 112 fawns were born per 100 does of breeding age. However, between 1951 and 1974 an average of only 49 fawns per 100 does survived to a year of age (average of April counts).

In 1959 and 1968, very heavy acorn crops were produced, especially on the deciduous oaks. With an abundance of acorns available from late August on, deer were in exceptionally good condition during the rut and on through those winters. We do not have detailed information on the numbers of fawns born in the spring of 1960 , but mature does ( 2 or more years old at breeding) collected during the winter of 1968-69 carried 1.75 fetuses per doe. The long-term average for mature does is about 1.5 fetuses per doe. Another indication of good reproduction in the fall of 1968 was our finding of a pregnant fawn in early 1969; this is the only pregnant fawn recorded at Hopland in some 24 years of intensive deer studies.

Our July counts for 1960 and 1969, respectively, were 101 and 83 fawns per 100 does, compared with the long-term July average of 69 . Following these two cohorts of fawns through to a year of age in April of 1961 and 1970, our counts showed survival rates of 78 and 70 per 100 does for the respective years, or increases above average of 59 and 43 percent.

From what is known of the nutritional relationships of deer to fawn survival, at least three possible factors may be involved which could account for these increases in fawn numbers (Verme, 1962). First, ovulation rates of does may have been increased as a 
result of improved nutrition before and during the rut. Second, good condition of does during gestation would be expected to lower neonatal mortality of fawns. Third, a carryover effect on the postpartum condition of fawns born in exceptionally vigorous condition may have contributed to better than average survival throughout their first year of life. All of these things may have occurred.

We suspect that the first two factors may have been of more relative importance than the third, but do not have sufficient data to substantiate this assumption. Also, other environmental factors may well have contributed to the observed increases in fawn numbers, but with the data at hand, any attempt to assess such effects would be speculative.

The nutritional effects of large acorn crops were also apparent in the age composition of bucks killed by hunters in 1960 and 1969-in each of these years, six yearling bucks with legal, forked antlers were taken. No more than one legal yearling was bagged in any other year, and in most years from 1954 through 1975 the youngest bucks taken were 2 years old. From these records it is clear that yearling bucks at Hopland normally produce only spike antlers, but they can grow larger, forked antlers under more ideal nutritional conditions. Severinghaus et al. (1950) observed a similar relationship between antler development and nutrition in white-tailed deer.

\section{Deer and sheep digestive tract comparisons}

As described by Longhurst and Douglas (1953) and Short, Medin, and Anderson (1965), deer have a relatively small digestive tract for their size compared with sheep and cattle. This relationship held true for all four stomach compartments, as well as the portions of the intestinal tract in the case of deer compared with sheep. However, Short, Medin, and Anderson (1965) only compared the rumen and reticulum of deer with those of a cow.

Longhurst and Douglas (1953) measured the water displacement of the various portions of the digestive tracts which contained food of a $30.4 \mathrm{~kg}$ deer and a $34.9 \mathrm{~kg}$ sheep of similar ages. By converting these body weights to metabolic weights (W 0.75), and comparing them to the total water displacement of their respective digestive tracts, it was evident that the digestive tract of the deer was only about 74 percent as large as that of the sheep.

These authors also compared the lengths of intestinal tracts of 10 deer and 8 sheep. The small intestines averaged $1,265 \mathrm{~cm}$ for deer and $2,484 \mathrm{~cm}$ for sheep, with average body weights of 25.9 and $25.4 \mathrm{~kg}$ respectively.

These crude comparisons indicate that deer apparently do not have the capacity to eat and digest the volume of food which sheep and cattle can utilize in relation to their size. On this basis it appears logical to assume that, on the average, deer need a higher quality diet to fulfill their nutritional requirements.

The data at hand on the respective diets of sheep and deer tend to confirm this hypothesis. Deei appear to shift their diet to a greater extent seasonally than do sheep to take more advantage of different kinds of forage plants, when they are in their most nutritious growth stages.

Both Weir and Torell (1959) and Van Dyne and Heady (1965b) have shown that sheep are selective in their choices of plant species and the parts of plants which they consume in order to maximize the nutrient content of their forage. However, sheep certainly seem to accept a much greater quantity of dry grass and forbs during the dry season than do deer. Deer maintain their intake of green forage at this season by shifting 
their diet to browse and summer-growing forbs, which are relatively high in protein and other desirable nutrients.

Considering the food requirements for deer and sheep mentioned earlier (2.35 percent of body weight for deer and 2.92 percent for sheep), it appears that sheep are adapted, by virtue of the larger capacity of their digestive tract, to handle a greater amount of forage. Sheep, therefore, have more freedom of choice in the nutritive quality of food plants they can consume and can afford to be less selective than deer.

\section{Forage competition between deer and sheep}

Perhaps "forage competition" is not the proper term to apply to this section of the report; it might be more appropriate to refer to an overlap in diets of the two animals. As long as sufficient forage of all categories is available for both species, even if deer and sheep were eating essentially the same kinds of plants, competition would not exist. However, when a shortage of any kind of forage is present, competition develops.

The rumen contents of deer and sheep indicate a certain amount of dietary overlap, which varies seasonally in relation to the changing diets of the two animals. Likewise, the amount of overlap in diet varies with the cover type, largely in response to differences in availability of certain forage plants.

The amount of overlap in diet was calculated in relation to the cover type where the deer were collected. As explained earlier, the sheep samples could not be correlated adequately with cover type, and for this reason, these comparisons in respect to cover type may lack validity, and comparison with the composite sample of all Hopland deer may be more meaningful.

Dietary overlap was calculated by the approach of Schoener (1968) where two species, $x$ and $y$, overlap to the extent that if $P_{x i}$ represents the frequency of utilization by species $x$ of the $i^{\text {th }}$ forage category, then overlap is expressed by:

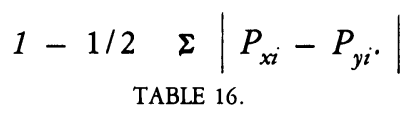

\begin{tabular}{|c|c|c|c|c|}
\hline Month & & Oak woodland & Chaparral & $\begin{array}{l}\text { Chaparral } \\
\text { oak woodland } \\
\text { ecotone }\end{array}$ \\
\hline \multicolumn{5}{|c|}{ Percent } \\
\hline January & & 79 & 13 & 50 \\
\hline February & & 62 & 10 & \\
\hline March & & 70 & 33 & \\
\hline April & & 27 & 6 & 32 \\
\hline May & & 10 & 24 & \\
\hline June & & 15 & 4 & \\
\hline July & & 12 & 14 & \\
\hline August & & 4 & 19 & 20 \\
\hline September & & 7 & $<1$ & 5 \\
\hline October & & 20 & $<1$ & 34 \\
\hline November & & 39 & 38 & \\
\hline December & & 32 & 13 & 22 \\
\hline \multicolumn{5}{|c|}{ General forage classes } \\
\hline Browse & & 3 & 6 & \\
\hline Forbs & & 7 & 1 & \\
\hline \multirow[t]{2}{*}{ Grass } & & 20 & 8 & \\
\hline & Total & 30 & 15 & \\
\hline
\end{tabular}

AMOUNT OF DIETARY OVERLAP OF FORAGE BY RANGE TYPE IN RUMEN SAMPLES OF DEER AND SHEEP*

\footnotetext{
* See tables 8 and 9 for specific identification of forage
} 
Table 16 indicates the extent of dietary overlap determined for the various cover-type categories which could be considered separately. It is evident that under existing stocking rates, deer and sheep overlap most in their diets when both are eating grass during the wet months of the year. Joint consumption of browse and forbs is minimal.

Dietary overlap is significantly greater in the oak woodland areas than in chaparral, principally because of the greater availability and consequent consumption of grass and forbs by deer in this cover type. As might be expected, deer from the area of mixed chaparral and oak woodland were intermediate in their overlap with sheep.

\section{Forage production compared with use by deer and sheep}

One of the pertinent aspects of forage interrelationships of sheep and deer is how forage production compares with consumption by the animals. Since such a comparison requires data not obtained in the present study, it was necessary to incorporate information gathered by other investigators to produce an estimate of forage production in the various cover types.

Combining data of Murphy (1970), Van Dyne and Heady (1965a) and Pitt (1975), an average production figure of $1939 \mathrm{~kg}$ of grasses and forbs per ha per year was derived for the grassland areas in the oak woodland cover type on the Hopland Field Station. Under dense stands of oak or other hardwoods, there is very little grass and forb production, especially if black oak, live oak, or scrub oak predominate. In general, grass and forb production varies inversely with oak stand density and is also related to the density of other hardwoods. Grass and forb production is especially low beneath both live and black oaks.

From 1963 through 1967, Jack Spruill of the California Department of Fish and Game collected acorns in meter ${ }^{2}$ traps set below the canopy of blue oaks at two elevations ( 305 and $884 \mathrm{~m}$ ) on the Hopland Field Station (unpublished data). He found that this species of oak dropped its acorns from late August until early December, and that the amount of acorns produced varied significantly from year to year $(0.14$ to $25.31 \mathrm{~kg}$ per tree per year). Variation was also significant among trees and between elevations. Twenty trees were sampled at each elevation, and the average production for all trees over the 5 -year period was $5.94 \mathrm{~kg}$ per tree per year.

Density of oaks per hectare varies greatly over the station, and the above estimates of acorn production would apply to the woodland grass and woodland cover types listed in table 1 but not to the chaparral. Considering that oak density ranges from less than 10 per ha to over 250 in some areas, a conservative average would certainly be at least 25 on the 1,110 ha involved in these two cover types. Even though acorn production was not sampled for all species, from the above figures it does not appear unreasonable to assume that at least $111 \mathrm{~kg}$ of acorns are produced annually per hectare per year, with an annual total for the station of approximately $123,000 \mathrm{~kg}$ (123 metric tons).

The amount of browse remaining within reach of deer and sheep in the woodland grass and woodland cover types is not great because of the distinct browse line which many years of heavy animal use has established on all of the palatable woody species. However, if the litter, consisting of leaves and wind-broken twigs and branches plus lichen and mistletoe (Phoradendron villosum), which falls from the woodland canopy, is considered to be partly usable as forage, production becomes much more significant.

From September, 1975, until early February, 1976, M. Fry of the Department of Forestry and Conservation of the University of California at Berkeley, measured acorn production and litter collected in a series of traps placed beneath oaks on the Hopland 
Field Station. Three of the dominant oak species were sampled: black oak, (Quercus kelloggii), blue oak (Q. douglasii), and interior live oak (Q. wislizenii).

The sampling period essentially covered the months when acorns and leaves drop from those species. Of the litter collected in the oak traps, the potentially usable forage items for deer and sheep consisted of sound acorns, leaves, and lichen. Although mistletoe occurs sporadically on deciduous oaks on the station and is eagerly sought by both deer and sheep, none was collected in Fry's traps.

Fry's data indicate that the total litter falling from the oak canopy in the woodland grass and woodland cover types probably exceeds $2,240 \mathrm{~kg}$ per ha annually in a good acorn year, but in a poor acorn year may be closer to $1,680 \mathrm{~kg}$ per ha. Those estimates are derived from a hypothetical "average" stand of oaks with a density of 25 trees per ha composed of 50 percent blue oak, 25 percent interior live oak, and 25 percent black oak.

Because much of the oak litter consists of coarse twigs, small limbs, and unsound acorns which would not be eaten by deer or sheep, the actual amount of potential forage would be much less than the above figures as explained earlier.

As in the other cover types, forage production in chaparral is variable, depending largely upon how recently the area has burned. The only body of pertinent data available was published by Taber (1956) for mature chaparral on the Cow Mountain area in the general vicinity of Boundary Basin.

Taber indicated that only about $202 \mathrm{~kg}$ of available browse are produced per ha each year by the major shrub species in mature chaparral. From the deer rumen analyses at hand which show their diet to be over 95 percent browse in this cover type, it appears that grasses and forbs are also in short supply, and it is doubtful if total annual forage production within reach of deer (including browse, forbs and grasses) exceeds $224 \mathrm{~kg}$ per ha.

Taber also showed that when chaparral is opened up by fire, total annual production of deer forage amounts to approximately $560 \mathrm{~kg}$ per ha, with a significantly higher proportion of grasses and forbs available than in mature chaparral. This probably approximates the situation in the mixed-age chaparral from which a number of our deer rumen samples were collected. Table 17 lists the estimated average production of the major classes of forage in the various cover types on the station. We recognize that the produc-

TABLE 17.

FORAGE PRODUCTION BY COVER TYPE, HOPLAND FIELD STATION

\begin{tabular}{|c|c|c|c|c|c|}
\hline Cover type & Forage class & $\begin{array}{c}\text { Average kg } \\
\text { per ha per year }\end{array}$ & $\begin{array}{l}\text { Hectares in } \\
\text { cover type }\end{array}$ & $\begin{array}{l}\text { Kilograms produced } \\
\text { on station }\end{array}$ & Source \\
\hline Grassland & Grass, forbs & 1939 & 435 & 843,465 & $\begin{array}{l}\text { Murphy (1970) } \\
\text { Van Dyne and Heady } \\
(1965 a) \text { Pitt }(1975)\end{array}$ \\
\hline \multirow[t]{4}{*}{ Woodland grass } & Grass, forbs & 1939 & 697 & $1,351,483$ & \\
\hline & $\begin{array}{l}\text { Acorns } \\
\text { Oak litter- }\end{array}$ & 112 & 697 & 78,064 & Spruill (Unpublished) \\
\hline & Leaves & 825 & 697 & 575,025 & Fry (Unpublished) \\
\hline & Lichen & 85 & 697 & 58,735 & \\
\hline \multirow[t]{4}{*}{ Woodland } & Acorns & 112 & 413 & 46,256 & Spruill (Unpublished) \\
\hline & Oak litter- & & & & \\
\hline & Leaves & 825 & 413 & 340,725 & Fry (Unpublished) \\
\hline & Lichen & 85 & 413 & 35,105 & \\
\hline \multirow{2}{*}{$\begin{array}{c}\text { Chaparral, } \\
\text { mature }\end{array}$} & Browse & 202 & $143^{*}$ & 28,886 & Taber (1956) \\
\hline & Grass, forbs & 22 & 143 & 3,146 & \\
\hline \multirow{2}{*}{$\begin{array}{l}\text { Chaparral, } \\
\text { mixed age }\end{array}$} & Browse & 560 & $143^{\star}$ & 80,080 & \\
\hline & Grass, forbs & 224 & 143 & 32,032 & \\
\hline
\end{tabular}

* Half of the chaparral on the field station is estimated to be mature, and half mixed age. 
tion of all forage classes can change significantly from year to year in response to a wide array of environmental variables. Therefore, the estimates in table 17 are primarily useful in providing a conceptual basis for comparing forage production with estimated use by deer and sheep.

In order to estimate the amount of range forage consumed, it was necessary to determine the average number of animals of each species present during the study period as well as their average weights. Animal numbers on the station were discussed earlier in the sections on the status of deer and sheep. Sheep numbers are also summarized in table 3.

However, to determine average stocking rates and animal weights, the various ages and sexes of the deer and sheep populations were weighted in respect to the amount of time they grazed on the station through the year and average weights of the subgroups.

For example, ewes and rams were on the station year-round, but lambs were marketed at approximately 4 months of age. The breeding ewe flock is also culled at about the same time the lambs are sold, and the culls are replaced with yearling ewes held over from the lamb crop of the previous year. The yearling ewes are in turn replaced by holding over some of the ewe lambs from the current year's crop.

Using weighted averages, it was determined that during the years of the study the average number of sheep on the station was 1,611 and the average weight of a sheep was $47.6 \mathrm{~kg}$. Weights of rams, ewes, and lambs were estimated to be $79.4,55.3$, and $19.1 \mathrm{~kg}$, respectively. Lamb weight was considered to be the birth weight $(4.1 \mathrm{~kg})$ plus half the gain to marketing at $34 \mathrm{~kg}$.

Sheep forage requirements were discussed earlier under the section on animal weights and forage requirements. Table 18 summarizes forage production and estimated consumption on the field station, using the percentages of diets of the two animals derived from the rumen sample analyses. As can be seen by examining column $\mathrm{H}$ of table 18 , production of all forage classes considered exceeds estimated consumption by significant margins except for chaparral browse. To estimate chaparral browse consumption, it was necessary to deduct the amounts of browse which deer and sheep probably obtained from oak litter. Even with those deductions, it is evident that consumption exceeded production by about 21 percent. Sheep are confined by the fenced boundaries of the station, and their access to additional browse is limited. However, those deer which had home ranges near the station boundaries are known to range out on to adjacent lands, and could thereby have access to additional browse supplies. At any rate, it appears that competition for available chaparral browse is the keenest of any class of forage on the station.

An example of the problems encountered in arriving at consumption estimates is the question of utilization of leaves shed from the oak canopy. We have shown that leaf fall probably amounts to over $916,000 \mathrm{~kg}$ annually on the station. The nutritional quality of leaves shed during the normal period of leaf drop in the late fall and winter is undoubtedly low, but branches with attached leaves which are broken off by wind or from other causes earlier in the season would have considerably more nutrient value.

Although the leaves shed by deciduous oaks in the late fall are low in food value, they are taken to some extent as shown in table 11. Consumption of black oak and blue oak occurs in December when most of the leaves would have dropped. Likewise, leaves from the valley oak are taken in December as well as in January and February. Our data do not disclose the proportions of oak browse from evergreen oaks (scrub oak and interior live oak) that are taken directly from the trees or from the ground. The same problem exists for deciduous oaks and other deciduous trees, such as buckeye, during the months when they retain their leaves. 
TABLE 18.

FORAGE PRODUCTION AND ESTIMATED CONSUMPTION BY DEER AND SHEEP, HOPLAND FIELD STATION

\begin{tabular}{|c|c|c|c|c|c|c|c|c|}
\hline \multirow[b]{2}{*}{ Forage class } & \multirow{2}{*}{$\begin{array}{l}\text { Kilograms produced } \\
\text { (to nearest thousand) } \\
\text { (A) }\end{array}$} & \multicolumn{2}{|c|}{ Percent of diet ${ }^{*}$} & \multicolumn{2}{|c|}{$\begin{array}{l}\text { Kilograms consumed } \\
\text { (to nearest thousand) }\end{array}$} & \multicolumn{3}{|c|}{$\begin{array}{l}\text { Percent of } \\
\text { production consumed } \mathrm{T}\end{array}$} \\
\hline & & $\begin{array}{l}\text { Deer } \\
\text { (B) }\end{array}$ & $\begin{array}{l}\text { Sheep } \\
\text { (C) }\end{array}$ & $\begin{array}{l}\text { Deer } \\
\text { (D) }\end{array}$ & $\begin{array}{l}\text { Sheep } \\
\text { (E) }\end{array}$ & $\begin{array}{c}\text { Deer } \\
(\mathbf{F})\end{array}$ & $\begin{array}{l}\text { Sheep } \\
\text { (G) }\end{array}$ & $\begin{array}{c}\text { Total } \\
\text { (H) }\end{array}$ \\
\hline Grass and forbs & $2,230,000$ & 27.8 & 93.8 & 56,000 & 638,000 & 2.5 & 28.6 & 31.1 \\
\hline Chaparral browse & 109,000 & 48.4 & 5.0 & 98,000 & 34,000 & 89.9 & 31.2 & 121.1 \\
\hline Acorns & 124,000 & 16.8 & 0.7 & 34,000 & 5,000 & 27.4 & 4.0 & 31.4 \\
\hline \multicolumn{9}{|l|}{ Oak litter: } \\
\hline Leaves & 916,000 & ca. $\quad 5.0$ & ca. 0.5 & ca. 10,000 & ca. 3,000 & 1.1 & ca. 0.3 & ca. 1.4 \\
\hline Lichen & $\begin{array}{l}94,000 \text { 虫 } \\
(75,000)\end{array}$ & 2.0 & $<0.1$ & 4,000 & $<1,000$ & 4.3 & ca. 1.1 & ca. 5.4 \\
\hline Total & $3,454,000 \S$ & 100.0 & 100.0 & $202,000^{\|}$ & $680,000 \#$ & 5.9 & 19.7 & 25.6 \\
\hline
\end{tabular}

* Deer rumen samples from all cover types (Table 8 for deer, Table 9 for sheep) used for this column.

I $\quad(F)=\frac{D}{A}$ for deer; $(G)=\frac{E}{A}$ for sheep

Very little lichen grows above ca. $820 \mathrm{~m}$ and in dense stands of mixed hardwoods and conifers. The total lichen produc-

tion, therefore, is estimated to be about $20 \%$ less or $75,000 \mathrm{~kg}$.

$\S$ Total calculated with lichen production estimated at $75,000 \mathrm{~kg}$.

II From Table 17.

\# Sheep lichen consumption is included in this total, although it maybe considerably less than $900 \mathrm{~kg}$.

TABLE 19.

ESTIMATED ANIMAL WEIGHTS AND FORAGE CONSUMPTION BY DEER AND SHEEP, HOPLAND FIELD STATION

\begin{tabular}{|c|c|c|}
\hline Item & Deer & Sheep \\
\hline Average weight $(\mathrm{kg})$ & 29.5 & 47.6 \\
\hline Feed as percent of body weight & $2.35^{\star}$ & $2.97^{\star}$ \\
\hline Ave. intake (kg/head/day) & 0.69 & 1.39 \\
\hline Ave. number animals on station & ca. 800 & 1,611 \\
\hline Ave. intake (kg/head/year) & ca. 252 & 507 \\
\hline Total feed required ( $\mathrm{kg} /$ year) & 201,600 & 816,777 \\
\hline Amount supplemented (kg/year) & 0 & ca. 137,000 \\
\hline Range forage consumed (kg/year) & ca. $202,000 \mp$ & $680,000 \mathrm{~T}$ \\
\hline $\begin{array}{l}\text { Average range forage consumed } \\
(\mathrm{kg} / \mathrm{ha} / \text { year })\end{array}$ & ca. 110 甲 & ca. $371 \mp$ \\
\hline
\end{tabular}

* Based on ca. $2.35 \mathrm{lb}$ forage per $100 \mathrm{lb}$ body weight for deer and ca. $2.92 \mathrm{lb}$ feed per $100 \mathrm{lb}$ body weight for sheep.

$\mp$ Rounded to nearest 1,000 .

Based on total of ha in various cover types given in Table 18 .

\section{Forage consumption and availability}

In our assessment of the relationships between forage consumption and availability, we attempted to compare estimated forage production on the Hopland Field Station with the nutritional requirements of the deer and sheep that were present. Taber and Dasmann (1958) used much the same system in their studies of chaparral habitat, although they did not base their estimate of consumption on the actual weights of individual deer in the population. They arbitrarily assumed an average weight of 45.4 $\mathrm{kg}$, whereas we calculated an average of $29.5 \mathrm{~kg}$ (table 19).

Van Dyne and Heady $(1965 a, b, c)$ compared the ratio of sheep and cattle dietary composition to range composition in the grassland of one pasture on the field station. They also considered the variation in the diets of individual animals at three periods during the summer but did not investigate other seasons of the year. Pudney (1972) used a similar approach in his Nevada deer study, although his information on abundance of vegetation was only based on ocular estimates and hence could not be precisely quantified. Petrides (1975) summarized a number of different studies of this problem and 
described a system of determining preference ratings for various forage species. He recognized that variations in preference exist for individual plant species in relation to the geographic area, stocking rate, and range condition.

Basically all of those investigators were concerned with the availability of forage species as related to their relative consumption by deer and livestock under various range conditions. They did not attempt to assess the "free-choice" preference of adequately fed animals under controlled conditions, as we did in our deer and sheep "cafeteria" feeding trials.

When animals are foraging under range conditions they are forced to make many compromises in their selection of food plants. With unlimited availability they could select their most preferred species and even the most preferred parts of those plants. However, such fortuitous circumstances seldom prevail on the range. The most favorable forage conditions for deer at Hopland occur from April through June and the worst in September and October, especially in years of low rainfall and poor acorn production.

Some of the dietary compromises which deer make and are able to withstand are evident in the various cover types we examined. For the most part, the food plant complexes growing on these areas are a reflection of basic site differences associated with soil types and precipitation levels. In part they also result from management practices including fire and logging. Yet another major influence on plant composition in these stands is the long-term impact of livestock and deer competing among themselves for the more highly preferred forage species.

All of these factors bear upon the relative carrying capacity of the various range types for both deer and sheep and are reflected in the numbers of animals of each species which can be supported. Unfortunately, our data are not adequate for a realistic comparison of year-round sheep carrying capacity in relation to cover type, because the sheep are primarily confined to the oak woodland areas that are interspersed with patches of mixed-age chaparral. Likewise, the sheep are supplemented seasonally to compensate for nutritional deficiencies in the range forage. Moreover, their numbers are regulated, thereby reducing intraspecific competition.

On the other hand, we can make certain comparisons of deer diets in relation to cover types on the field station. Figure 10 indicates the percent volume of the major forage classes (browse, grass and forbs) found in the deer rumen samples collected in two adjacent cover types (oak woodland and mixed age chaparral) as well as in the ecotone between them. These same seasonal relationships are shown in tables 11,12 , and 13 and figures 5, 6, and 7, but figure 10 shows the comparisons somewhat more graphically.

Presumably, deer that live in the ecotone have a greater choice of food plants available to them than do those deer that are restricted to either the chaparral or oak woodland. It is reasonable, therefore, to conclude that the ecotone or "edge" situation is a better habitat than the adjacent areas but even so may not be ideal. The extensive summary of Rocky Mountain mule deer food habits by Kufeld, Wallmo, and Feddema (1972) indicates the range of diets encountered in varying habitats.

From the seasonal shifts in deer diets in these three range types, we surmise that in the spring months deer would prefer to have more forbs and grass than are available in the chaparral. In summer the oak woodland does not appear to supply adequate browse, while in fall this same situation seems to persist although not quite to the same extent. During the winter, too, oak woodland deer seem to be short of browse, while chaparral deer are not able to obtain sufficient grass. The forb supply in chaparral, surprisingly, appears to be nearly adequate in winter.

Browning and Lauppe (1964) compared the diet of the Masonite deer with that on the 
Rockport Redwood Company property. The Rockport property lies closer to the coast and more within the redwood belt than the Masonite study area. Airline, the Rockport area is approximately $64 \mathrm{~km}$ northwest of the Masonite study site.

On the Rockport area, the vegetation is in an earlier successional stage than at Masonite, having been burned and logged at various times from 5 to 18 years before the deer rumen samples collections were made from 1961 to 1963. As would be expected under these conditions, an abundance of browse would be available to deer, and this was reflected in the rumen samples which averaged approximately 50 percent browse, 30 percent forbs, and 20 percent grass. Data on the Masonite deer (which had only about 20 percent browse, 16 percent forbs, and 64 percent grass in their diet) confirms our judgment that palatable browse was in short supply there.

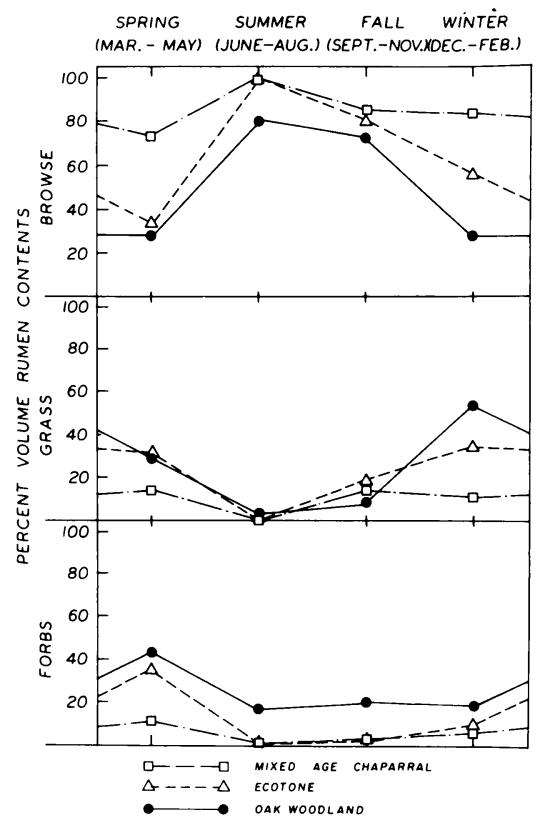

Fig. 10. Seasonal differences in deer diets associated with cover type.

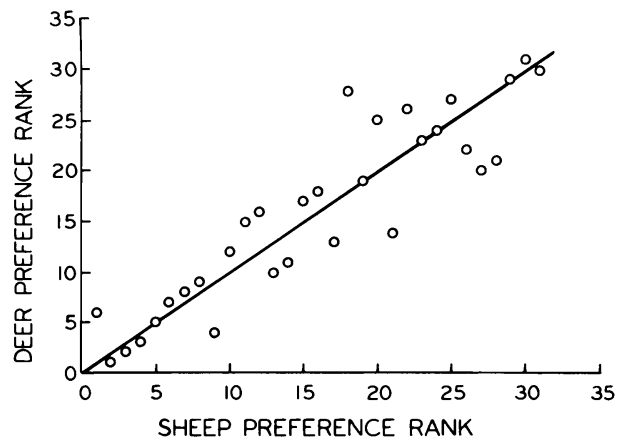

Fig. 11. Relationship between deer and sheep preference ranks for selected browse species tested in 1963 cafeteria feeding trials (see Tables 4 and 5; slope $=1.0$ ).
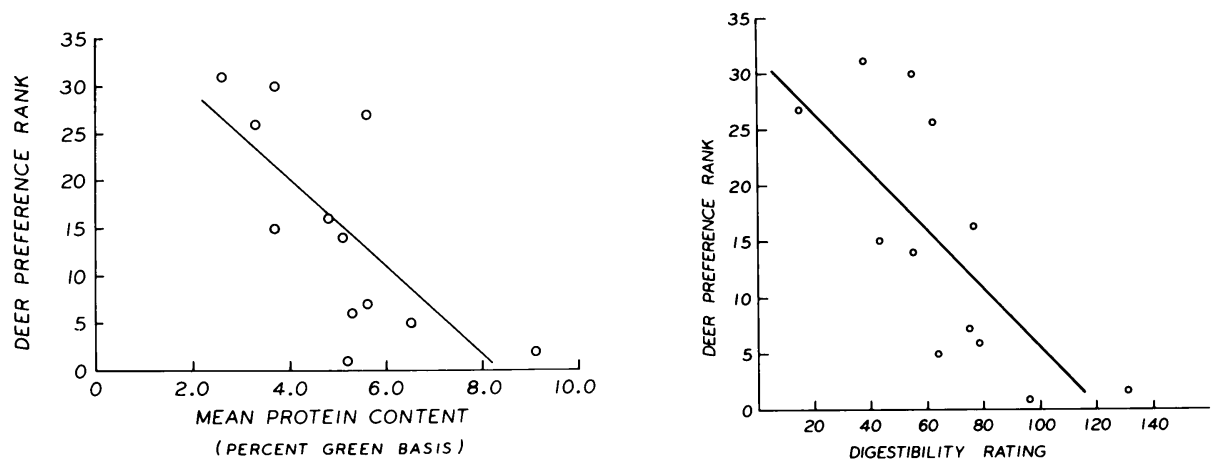

Fig. 12. Relationship between deer preference rank and mean protein content (green basis) for browse species tested in 1962 cafeteria feeding trials (see Table 6 ). Fitted regression line shown is $Y=29.20-2.81 x$.

Fig. 13. Relationship between deer preference rank and digestibility rank of 12 selected browse species (see Table 20). Fitted regression line shown is $\mathrm{Y}=38.39-4.64 \mathrm{x}$. 
As we have shown, deer can adjust their diet in relation to differing availability of forage species associated with cover types, or in response to changes in stocking rate and consequent intraspecific competition. This was demonstrated by Nellis and Ross (1969) when they compared the food habits of the mule deer herd on the National Bison Range in Montana before and after it was reduced by shooting.

Following the reduction in deer numbers, the use of browse increased significantly with a commensurate reduction in forb and grass intake. It was not clear whether browse supplies actually increased, or if the amount of available browse per deer merely increased as a function of less competition. The pertinent point, however, is that at the Bison Range, in the case of our ecotone deer, and at Rockport, when more browse was available, deer took advantage of it.

\section{Analysis of browse preference data from cafeteria feeding trials}

To examine the data collected uring the 1962 cafeteria feeding trials of deer and sheep preferences for 31 browse species, we first tested the correlation between the preference ranking of the two animals. We found that there was in fact a highly significant Spearman rank correlation (figure $11, \mathrm{r}_{\mathrm{s}}=0.91, \mathrm{n}=31, \mathrm{P}<.001$ ) indicating that among the browse species tested both deer and sheep tend to select and reject the same plants.

We next tested to determine whether phosphorus content influenced preference. The data from table 8 were used to divide the browse species into three groups (highly preferred, moderately preferred and unpalatable). The difference in phosphorus content between these three groups was not significant by one-way analysis of variance $(F=0.3692$, d.f. $=2,27)$. We did, however, find that there was a significant correlation between deer preference ranking (table 6 ) and the plant protein levels determined on the green basis (GPC), but with large variation (figure 12, $\mathrm{r}_{\mathrm{s}}=0.407, \mathrm{n}=31, \mathrm{P}<0.05$ ). For sheep the same trend is seen, but the correlation is not significant $\left(r_{s}=.256, n=31\right.$, $P>0.10)$. For both sheep and deer there was no significant correlation between preference rank and dry protein content in dry samples.

Some previous work has suggested, however, that digestibility of plants has an important bearing on preference. Longhurst et al. (1968) reported in vitro digestibility trials for 12 of the same browse species dealt with in the cafeteria feeding trials (table 20). The correlation between deer preference rank (DPR) and digestibility rating (DR) is

TABLE 20

DEER PREFERENCE, PROTEIN CONTENT AND IN VITRO DIGESTIBILITY OF 12 SELECTED BROWSE SPECIES

\begin{tabular}{lccc}
\hline Browse species & $\begin{array}{c}\text { Deer } \\
\text { preference } \\
\text { rank }\end{array}$ & $\begin{array}{c}\text { Protein } \\
\text { content } \\
\text { (gm/100 gm) } \\
\text { wet weight }\end{array}$ & $\begin{array}{c}\text { Percent } \\
\text { relative } \\
\text { digestibility } \\
\text { compared to alfalfa }\end{array}$ \\
\hline Mistletoe & 1 & 5.2 & 96 \\
Lichen & 2 & 9.1 & 132 \\
Valley oak & 5 & 6.5 & 63 \\
Black oak & 6 & 5.3 & 79 \\
Blue oak & 7 & 5.6 & 76 \\
Scrub oak & 14 & 5.1 & 57 \\
Chamise & 15 & 3.7 & 42 \\
Live oak & 16 & 4.8 & 77 \\
Silk tassel & 26 & 3.3 & 62 \\
California bay & 27 & 5.6 & 15 \\
California nutmeg & 30 & 3.7 & 56 \\
MacNab cypress & 31 & 2.6 & 38 \\
\hline
\end{tabular}

SOURCE: Longhurst, et al., 1968. 
highly significant $\left(\mathrm{r}_{\mathrm{S}}=0.811, \mathrm{n}=12, \mathrm{P}<.005\right.$, Fig. 13). It might be argued that this correlation is due to a correlation between digestibility and protein content. To examine the relationship of preference rank to digestibility and protein content, we calculated the partial Spearman correlation coefficients (Conover, 1971: 254). These indicate that the relationship of preference to digestibility is stronger partial $r_{S}=.749$ ) than the relationship of preference to protein content (partial $r_{s}=.588$ ).

Interpretation of these relationships by such tests of correlation is beset by problems, however. Preference rank can be expressed numerically, but it is unlikely that the scale is linear. Unit differences in preference rank are not all of the same magnitude, because a plant species rank merely indicates its position relative to other species.

Because of such problems, only correlations significant to at least the one percent level were reported. These correlations imply that preference for a plant species by deer increases with its protein content and its digestibility. This is not surprising, because from a physiological standpoint digestibility by rumen microbes would be improved by increasing the protein content. Digestibility would also be expected to improve if the content of readily fermentable carbohydrates was increased. Conversely, increases in lignin content would tend to reduce digestibility, because lignin acts to mechanically block access to digestible plant-cell constituents by rumen microbes. Likewise, if secondary plant compounds having antimicrobial properties are present in sufficient concentration, they would tend to depress digestibility.

We suspect that the net balance of all of these positive and negative factors determines the ultimate digestibility of a plant at any particular growth stage, but we cannot yet specify precisely which clues these ruminants use when choosing food items. Other investigators (Radwan, 1972, 1974, 1975; Radwan and Crouch, 1974) have studied relationships between food preferences of deer and various chemical constituents of browse plants, but they too have not found clear-cut correlations. Chlorogenic acid is the only chemical which has shown some consistency in terms of positive correlation with deer preference (Radwan, 1972, 1975), but the biological role of this chemical is unclear. This area of investigation is promising for further study.

\section{Deer and sheep effects on range vegetation}

The effects of range vegetation on deer and sheep have just been examined, and it is appropriate now to consider some of the effects of these animals on the vegetation. Unfortunately, our data are insufficient to assess these effects quantitatively, but some of the more obvious results of grazing and browsing can be pointed out.

Burcham (1957) described the coming of livestock to California and its impact on the rangelands. The Hopland Field Station retains remnants of the native perennial grass species that dominated the pristine grasslands. With the livestock came a mixture of European annual grasses and forbs, and these are now the most abundant forms.

Given protection from sheep grazing, a number of changes take place in the species composition of grasslands. These have been described by Heady $(1958,1977)$. When sheep grazing pressure is removed, taller grasses including the introduced wild oats (Avena spp.), rip gut brome (Bromus rigidus) and the native perennials of the genera Stipa, Sitanion, Melica and Elymus increase in density. Native legumes, composites, and filaree would be expected to decrease. We have observed these changes at the field station in areas which have been protected from sheep grazing. This is illustrated in figure 14, which shows an area of Hopland Field Station where both deer and shee grazing had been excluded for 19 years. The native perennial, Stipa pulchra, had 
become dominant over the typical stand of mixed introduced annuals, which had formerly covered the site. In certain other areas of the state, however, similar changes in the species composition of protected grasslands have not been observed. For example, in the University's Hastings Reserve in Monterey County, and in Sequoia National Park in Tulare County, introduced annuals which have been protected from grazing have not been as completely replace by native perennials.



Fig. 14. Grassland protected from deer and sheep grazing on the Hopland Field Station. Foothill stipa (Stipa pulchra) is the dominant native perennial.

Another aspect of the impact of sheep grazing on grassland areas is the synergistic effect on deer forage. Without sheep grazing, the density of native perennial grasses increases at the expense of the introduced annuals, such as soft chess (Bromus mollis) and filaree (Erodium botrys) that deer prefer. Deer grazing alone does not maintain grasslands in the most productive condition for deer-carrying capacity.

The oak tree shown in figure 15 has been protected from both deer and sheep use since 1956, a period of 20 years, while figure 16 shows the normal browse line resulting from deer and sheep use. However, in 1961, after only five years of protection, a comparison was made with a grazed pasture. No oak seedlings were found in the grazed area, but in the protected pasture seedlings averaged 554 per acre. With virtually no replacement of oak stands under the combined weight of deer and sheep use, it is obvious that over the years this important source of browse and mast will gradually be reduced as trees mature and die. Arboreal lichens, which grow primarily on oak trees, will also decline in production, and this will contribute to the overall decline in range carrying capacity. Use of oak seedlings by deer and sheep is obviously only part of the problem. Pocket gophers (Thomomys bottae), for example, are also known to utilize these seedlings (Griffin, 1971). 


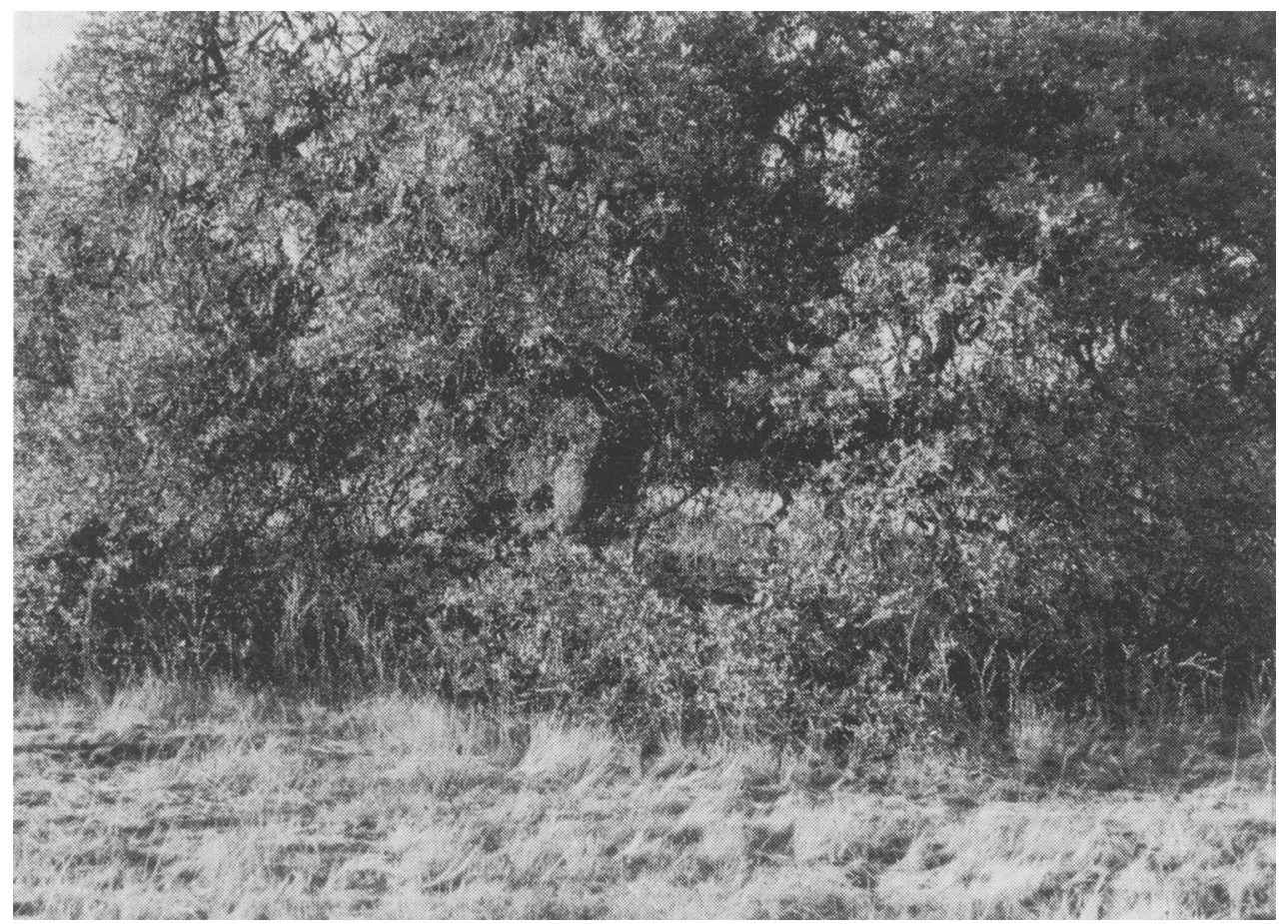

Fig. 15. Blue oak (Quercus douglasii) protected from deer and sheep browsing for 20 years on the Hopland Field Station.

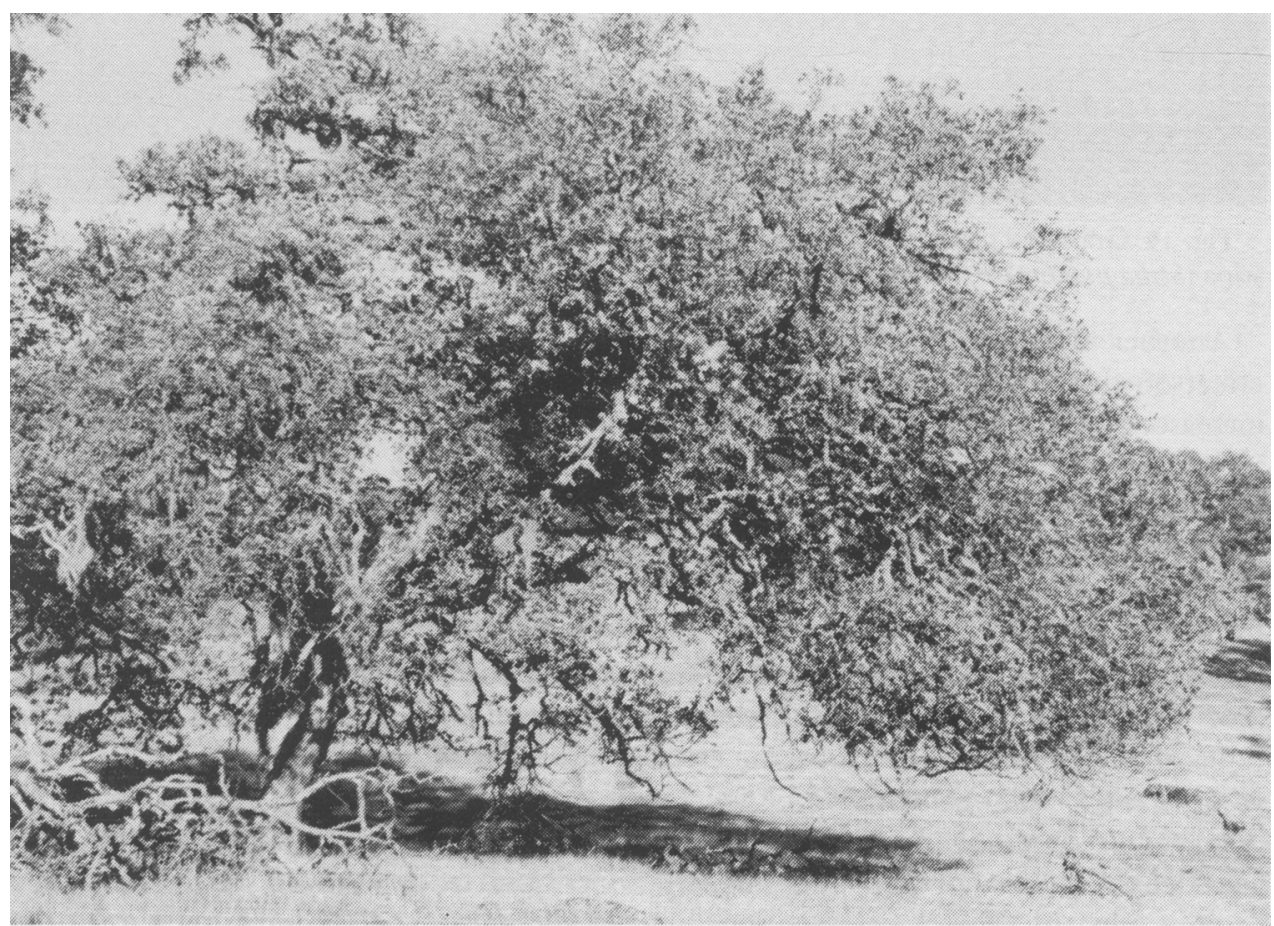

Fig. 16. Blue oak (Quercus douglasii) exposed to deer and sheep browsing on the Hopland Field Station. 


\section{CONCLUSIONS}

Under the conditions present on the Hopland Field station, there is little significant competition between deer and sheep for most kinds of range forage. In the chaparral there is an apparent shortage of palatable browse, but at Hopland there is little opportunity for competition between deer and sheep in chaparral types because sheep spend little time in chaparral. In fall, there may be some competition for the green forage that is in short supply (Anderson, et al. 1974). On the whole, however, food habits of deer and sheep are complementary on oak woodland ranges, and dual stocking makes more efficient use of all forage than would exclusive use by either class of stock.

Cafeteria feeding trials indicated that deer and sheep use their sense of smell to select preferred browse species. In general, deer and sheep show similar preferences. No correlation was found between preference and phosphorus content or with protein levels in dry samples, but deer preference did appear to be correlated with protein expressed on a green or fresh weight basis. This is logical, because deer made their selections from fresh, green browse samples, but we were unable to show a similar correlation for sheep. More importantly, we cannot show that deer or sheep detect protein content as a direct criterion of acceptability. The actual clues sought by the animals remain unknown, and will probably continue to evade detection by such simplistic approaches as protein or phosphorus determination. We suspect that dessication, even wilting, may alter the amount of volatile compounds present in fresh vegetation, thereby changing its odor and in turn affecting the animals' preferences, but we did not compare green with dry samples in cafeteria trials.

In any given forage situation, deer and sheep tend to select the preferred food plants, but if these are not available in sufficient quantity to meet their needs, they turn to less preferred species. Since the most preferred plants are almost always in short supply, they tend to furnish only a small fraction of the diet.

Because of their relatively larger digestive tracts, sheep probably can subsist on lower quality forage than that required by deer, and compensate by processing a larger quantity of food. On the other hand, deer may meet their requirements for a higher quality diet by being more selective for most nutritious plants; also they shift their diet more frequently to take advantage of the differing patterns of seasonal growth which are characteristic of certain forage species. Our investigations of deer diets in contrasting habitats showed that they can tolerate a wide latitude in their diets. We believe that when deer subsist on a sub-optimum mixture of forage, range-carrying capacity is accordingly reduced and numbers decline. At the Hopland Field Station, deer densities are higher in oak woodland than in chaparral habitats. The diet provided by the oak woodland plant community is apparently more nearly optimum for deer than is the diet in chaparral.

Sheep grazing seems to maintain oak-woodland vegetation in a productive seral stage for deer, maintaining higher carrying capacity than would exist without sheep use. However, the level of browsing that occurs on the field station appears to prevent oak seedling establishment. If the present trend continues, the gradual loss of the oak trees will reduce the production of browse, mast, and arboreal lichens. To the deer manager, this is obviously a matter of concern, because since the deer in oak woodland habitats currently rely on the oaks for approximately half of their food (table 11).

Oak reproduction is sparse on the Hopland Field Station, even in pastures from which sheep have been excluded for 20 or more years. Therefore the browsing pressure of deer alone appears to prevent establishment of new oak trees. Our limited experience with 
small, fenced pastures, however, indicates poor oak reproduction even when both deer and domestic livestock are completely excluded. For this reason we cannot attribute the current lack of oak reproduction at Hopland solely to browsing by ungulates. Moisture stress during the dry season and competition with other plants may also be of importance. This subject needs further research.

Differences in acorn crops from year to year seem to be one of the most important variables in annual forage supplies. Deer are affected more than sheep by changes in acorn availability, and fawn production and survival can be significantly affected.

Overall, we conclude that a large array of environmental, behavioral, physiological, anatomical and ecological factors must be considered to obtain a comprehensive understanding of the food interrelationships of livestock and big game on rangelands.

\section{ACKNOWLEDGMENTS}

We wish to acknowledge the generous assistance which many individuals and organizations have contributed to these investigations. Special thanks are due to: A. H. Murphy, D. T. Torell, M. B. Jones, and other at the Hopland Field Station who helped with many phases of the studies; the California Department of Fish and Game for Cooperation in collections of deer samples and analysis of rumen samples at their Fish and Game Field Station; J. Spruill, California Department of Fish and Game, for his data on acorn production; M. Fry, Department of Forestry and Conservation, U.C. Berkeley, for his records of oak litter and acorn production; R. D. Taber, University of Washington, for assistance with interpretation of his data on chaparral browse production; the Masonite Corporation, and in particular, to J. P. Sweeley for assistance with field collections on their property; and G. S. Colgrove for assistance in preparing the manuscript. 


\section{LITERATURE CITED}

ANDERSON, F.M., G.E. CONNOLLY, A.N. HALTER, and W.M. LONGHURST

1974. A computer simulation study of deer in Mendocino County, California. Ore. Agr. Expt. Sta. Tech. Bull. 130, 72 pp.

ANTHONY, R.G., and N.S. SMITH

1974. Comparison of rumen and fecal analysis to describe deer diets. J. Wildl. Mgt. 35:535-40.

BUECHNER, H.K.

1950. Life history, ecology and range use of pronghorn antelope in Trans-Pecos Texas. Amer. Midland Natur. 43:257-354

BISSELL, H.D., B. HARRIS, H. STRONG, and F. JAMES

1955. The digestibility of certain natural and artificial foods eaten by deer in California. Calif. Fish and Game 41:57-78.

BJUGSTAND, A.J., H.S. CRAWFORD, and D.L. NEAL

1970. Determining forage consumption by direct observation of domestic grazing animals. USDA For. Serv. Misc. Publ. 1147:101-04.

BOOK, S.A., G.E. CONNOLLY, and W.M. LONGHURST

1972. Fallout ${ }^{137} \mathrm{Cs}$ accumulation in two adjacent populations of northern California deer. Health Phy. 22:379-85.

BRIDGER, G.L., D.R. BOYLAND, and J.N. MARKEY

1953. Colorimetric determination of phosphorous pentoxide in fertilizers using a standard calibration plot. Anal. Chem. 25:336-38.

BROWNING, B.M., and E.M. LAUPPE

1964. A deer study in a redwood-Douglas fir forest type. Calif. Fish and Game 50:132-147.

BURCHAM, L.T.

1957. California range land. Calif. Division of Forestry. Sacramento, Ca., 261 pp.

CONNOLLY, G.E.

1970. A population model for deer on the Hopland Field Station, Mendocino County, California. M.A. Thesis, Sonoma State College, Rohnert Park, Ca., 54 pp.

CONNOLLY, G.E., and W.M. LONGHURST

1975. Deer production at Hopland Field Station. Calif. Agr. 29:8-9.

CONOVER, W.J.

1971. Practical non-parametric statistics. John Wiley and Sons, Inc. N.Y., 462 pp.

DRAWE, D.L. and T.W. BOX

1968. Forage ratings for deer and cattle on the Welder Wildlife Refuge. J. Range Mgt. 21(4):225-28.

EBERHARDT, L.L.

1969. Population analysis. In Wildlife Management Techniques (R.H. Giles, Jr., Ed.), The Wildlife Society, Wash., D.C., pp. 457-95.

FREELAND, W.J., and D.H. JANZEN

1974. Strategies in herbivory by mammals: The role of plant secondary compounds. Amer. Naturalist 108 (961):269-89.

GOWANS, K.D.

1958. Soil survey of the Hopland Field Station. Univ. of Calif. Agr. Expt. Sta., Dept. Soils and Plant GRIFFIN, J.R. Nut., Davis, 34 pp., 1 Map.

1971. Oak regeneration in the upper Carmel Valley, California. Ecology 52:862-68.

HEADY, H.F.

1958. Vegetational changes in the California annual type. Ecology 39:402-16.

1964. Palatability of herbage and animal preference. Jour. Range Mgt. 17(2):76-82.

1977. Valley grasslands. In Terrestrial Vegetation of California (M.G. Barbour and J. Major, Eds.) N.Y.: Wiley and Sons. 491-514.

HEADY, H.F., and J.I. MALIORY

1955. Cover type map of the Hopland Field Station. Univ. of Calif. Agr. Expt. Sta.

HITCHCOCK, A.S.

1951. Manual of the grasses of the United States. USDA Misc. Publ. 200, 1051 pp.

HORWITZ, W. (ED.)

1960. Improved Kjeldal method for nitrate-free samples. Method No. 2.036. In Official Methods of Analysis of the Association of Official Agricultural Chemists, 9th Edition, A.O.A.C., Washington D.C.

KELKER, G.H

1940. Estimating deer populations by differential hunting loss in the sexes. Utah Acad. Sci., Arts, and

KELKER, G.H. Let., Proc. 17:65-69.

1943. Sex ratio equations and formulas for determining wildlife populations. Utah Acad. Sci., Arts and Let., Proc. 20:189-98. 
KLEIN, D.R.

1962. Rumen contents analysis as an index to range quality. Trans. N. Amer. Wild. Conf. 27:150-64.

KUFELD, R.C., O.C. WALLMO, and C. FEDDEMA

1973. Foods of the Rocky Mountain mule deer. USDA Forest Service Res. Paper, RM-111, 31 pp.

LINCOLN, F.C.

1930. Calculating waterfowl abundance on the basis of banding returns. USDA Circ. No. 118, 4 pp.

LONGHURST, W.M., and G.E. CONNOLLY

1970. The effects of brush burning on deer. Trans. Ann. Mtg. Calif.-Nev. sections, The Wildl. Soc. and Amer. Fisheries Soc., pp. 139-55.

LONGHURST, W.M., and J.R. DOUGLAS

1953. Parasite interrelationships of domestic sheep and Columbian black-tailed deer. Trans. N. Amer. Wildl. Conf. 18:168-88.

LONGHURST, W.M., H.K. OH, M.B. JONES, and R.E. KEPNER

1968. A basis for the palatability of deer forage plants. Trans. N. Amer. Wildl. and Natur. Res. Conf. 33:181-92.

MARTIN, A.C., R.H. GENSCH, and C.P. BROWN

1946. Alternate methods in upland game bird food analysis. Jour. Wildl. Mgt. 10:8-12.

MACKIE, R.J.

1970. Range ecology and relations of mule deer, elk and cattle in the Missouri River breaks, Montana. Wildl. Mono. 20, 79 pp.

MEDIN, D.E.

1970. Stomach content analyses: collections for wild herbivores and birds. Range and Wildlife Habitat Evaluation-A Research Symposium. USDA, For. Serv., Misc. Publ. No. 1147:133-45.

MCKEAN, W.T., and R.W. BARTMANN

1971. Deer-livestock relations on a pinyon-juniper range in northwestern Colorado. Colo. Dept. Game, Fish \& Parks. 132 pp.

MUNZ, P.A., and D.D. KECK

1975. A California flora and supplement. University of California Press, $1681(+224) \mathrm{pp}$.

MURPHY, A.H.

1970. Predicted forage yield based on fall precipitation in California annual grasslands. Jour. Range Mgt. 23:363-65.

NATIONAL ACADEMY OF SCIENCES, NATIONAL RESEARCH COUNCIL, SUBCOMMITTEE ON SHEEP NUTRITION

1975. Nutrient requirements of sheep. Nutrient Requirements of Domestic Animals Series. (5th revised NEFF, D.J. ed.) 1963, $72 \mathrm{pp}$.

1974. Forage preferences of trained mule deer on the Beaver Creek watersheds. Ariz. Game \& Fish Dept. Spec. Rept. No. 4, 61 pp.

NELLIS, C.H., and R.L. ROSS

1969. Changes in mule deer food habits associated with herd reduction. Jour. Wildl. Mgt. 33:191-95.

NORRIS, J.J.

1943. Botanical analysis of stomach contents as a method of determining forage consumption of range sheep. Ecology 24:244-51.

OVERTON, W.S.

1969. Estimating numbers of animals in wildlife populations. In Wildlife Management Techniques (R.H Giles, Jr., Ed.) The Wildlife Society, Wash. D.C., 403-55.

PETRIDES, G.A.

1975. Principal foods versus preferred foods and their relations to stocking rate and range condition.

PITT, M.D. Biol. Conserv. 7:161-69

1975. The effects of site, season, weather patterns, grazing, and brush conversion on annual vegetation, watershed II, Hopland Field Station, Ph.D. Thesis, Univ. of Calif., Berkeley, 281 pp.

PUDNEY, R.A.

1972. Food preference of mule deer on the Ruby Butte study area. M.S. Thesis. Univ. Nevada, Reno, $95 \mathrm{pp}$.

RADWAN, M.A.

1972. Differences between Douglas-fir genotypes in relation to browsing preference by black-tailed deer. Canadian J. For. Res. 2:250-55.

1974. Natural resistance of plants to mammals. pp. 85-94 In Wildlife and Forest Management in the Pacific Northwest, Symposium Proc., Ore. State Univ. Press, Corvallis.

1975 Genotype and season influence chlorogenic acid content in Douglas-fir foliage. Can. J. Forest Res. 5:281-84. 
RADWAN, M.A., and G.L. CROUCH

1974. Plant characteristics related to feeding preference by blacktailed deer. J. Wildl. Mgt. 38:32-41.

RICE, R.W.

1970. Stomach content analyses: a comparison of the rumen vs. esophageal techniques. USDA For.

SCHOENER, T.W Serv. Misc. Publ. 1147:127-32.

1968. The anolis lizards of Bimini: resource partitioning in a complex fauna. Ecology 49:704-26.

SEVERINGHAUS, C.W., H.F. MACGUIRE, R.A. COOKINGHAM, and J.E. TANCK.

1950. Variations by age class in the antler beam diameters of white-tailed deer related to range conditions.

Trans. N. Amer. Wildl. and Nat. Res. Conf. 15:551-70.

SHORT, H., D.E. MEDIN, and A.E. ANDERSON

1965. Ruminoreticular characteristics of mule deer. Jour. Mamm. 46:196-99.

SKOVLIN, J.M., P.J. EDGERTON, and R.W. HARRIS

1968. The influence of cattle management on deer and elk. Trans. N. Amer. Wildl. Conf. 33:169-81.

TABER, R.D

1956. Deer nutrition and population dynamics in the north coast range of California. Trans. N. Amer. Wildl. Conf. 21:159-72.

TABER, R.D., and R.F. DASMANN

1958. The black-tailed deer of the chaparral. Calif. Dept. Fish and Game, Bull. 8, 163 pp.

THEURER, B.

1970. Chemical indicator techniques for determining range forage consumption. USDA For. Serv. Misc. Publ. 1147:111-19.

VAN DYNE, G.M., and H.F. HEADY

1965 a Botanical composition of sheep and cattle diets on a mature annual range. Hilgardia 36:465-92.

19656 Dietary chemical composition of cattle and sheep grazing in common on a dry annual range. Jour. Range Mgt., 18:78-85.

1965c. Interrelations of botanical and chemical dietary components of animals grazing dry annual range. Jour. Anim. Sci. 24:305-12.

VAN DYNE, G.M. and J.H. MEYER

1964. Forage intake by cattle and sheep on dry annual range. Jour. Anim. Sci. 23:1108-15.

VAN DYNE, G.M., and D.T. TORELL

1964. Development and use of the esophageal fistula: a review. Jour. Range Mgt. 17:7-19.

VERME, L.J.

1962. Mortality of white-tailed deer fawns in relation to nutrition. Proc. 1st Nat. White-tailed Deer Dis. Symp. 1:15-38.

WALLMO, O.C., R.B. GILL, L.H. CARPENTER, and D.W. REICHERT

1973. Accuracy of field estimates of deer food habits. J. Wildl. Mgt. 37:556-62.

WILUIAMS, O.C., and D.J. NEFF

1970. Direct observations of tamed deer to measure their consumption of natural forage. USDA For. Serv. Misc. Publ. 1147:1105-10.

WARD, A.L.

1970. Stomach content and fecal analysis: methods of forage identification. USDA For. Serv. Misc. Publ., 1147:146-58.

WEIR, W.C., and D.T. TORELL

1959. Selective grazing by sheep as shown by a comparison of the chemical composition of range and pasture forage obtained by hand clipping and that collected by esophageal-fistulated sheep. Jour. Anim. Sci. 18:641-49. 
